\title{
Penerapan Asuhan Keperawatan Jiwa Dengan Gangguan Proses Pikir: Waham Kebesaran Pendekatan Strategi Pelaksanaan (SP) 1-4: Studi Kasus
}

\section{*Melania Syahfitri', Rudy Desfanta Tarigan², Doni Syahdi³ ${ }^{3}$ Fahrini Syafitri ${ }^{4}$, Jek Amidos Pardede ${ }^{5}$}

\section{*Melanisyahfitri777@gmail.com}

\section{BAB 1}

\section{PENDAHULUAN}

\subsection{Latar Belakang}

Skizofrenia adalah suatu bentuk psikosa fungsional dengan gangguan utama pada proses pikir serta disharmoni (keretakan, perpecahan) antara proses pikir, afek atau emosi, kemauan dan psikomotor disertai distorsi kenyataan, terutama karena waham dan halusinasi, asosiasi terbagi-bagi sehingga timbul inkoherensi (Direja, 2016). Gejala skizofrenia dapat mengalami perubahan semakin membaik atau semakin memburuk dalam kurun waktu tertentu, hal tersebut berdampak dengan hubungan pasien dengan dirinya sendiri serta orang yang dekat dengan penderita (Pardede, 2015).

Skizofrenia juga ditandai dengan gangguan pada proses pikir, dan juga disertai adanya ekspresi emosi yang tidak wajar (Sulistyono, dkk, 2018). Gejala skizofrenia dibagi menjadi dua kategori, yang pertama yaitu positif ditandai dengan adanya waham, halusinasi, disorientasi pikiran, bicara dan perilaku yang tidak teratur. Salah satu jenis gangguan jiwa skizofrenia adalah skizofrenia paranoid. Secara klasik skizofrenia tipe paranoid ditandai terutama oleh adanya gangguan waham. Waham merupakan salah satu gangguan orientasi realitas. Gangguan orientasi realitas adalah ketidakmampuan klien menilai dan berespons pada realitas, klien tidak dapat membedakan lamunan dan kenyataan sehingga 
muncul perilaku yang sukar untuk dimengerti dan menakutkan (Kusumawati, 2018).

Menurut ECA (2021) Prevelensi Amerika Serikat askizofrenia telah meningkat dari 30\% jiwa. Prevalensi skizofrenia yang cukup tinggi bukan hanya di dunia tetapi di Indonesia juga mengalami hal yang sama. Riset Kesehatan Dasar (Riskesdas) 2018 menunjukkan, prevalensi skizofrenia/psikosis di Indonesia sebanyak 6,7 per 1000 rumah tangga. Artinya, dari 1.000 rumah tangga terdapat 6,7 rumah tangga yang mempunyai anggota rumah tangga (ART) pengidap skizofrenia/psikosis. Sedangkan Provinsi Sumatera Utara berada pada posisi ke 21 dengan privalensi 6,3\% (Kemenkes, 2019). Penelitian yang dilakukan Christenson, dkk. Di sebuah komunitas orang tua di San Francisco, mereka yang dinilai memiliki gangguan kejiwaan mengalami gejala kecurigaan sebanyak $17 \%$ dan yang memiliki gangguan proses pikir waham sebanyak 13\% (Asis, 2018).

Gangguan proses pikir waham biasanya dianggap sulit untuk diobati (Skelton, 2015). Pada populasi umum gangguan proses pikir waham memiliki prevalensi sekitar $0,18 \%$, sedangkan prevalensi pada rawat inap psikiatris antara 1 dan $4 \%$. Prevalensi gangguan proses pikir waham sebenarnya cenderung lebih tinggi, dikarenakan kurangnya wawasan dalam mencegah serta mencari bantuan dalam mengenali penyakit tersebut (Rowland, 2019).

Menurut Rusdi (2020) Waham adalah keyakinan klien yang tidak sesuai dengan kenyataan yang tetap dipertahankan dan tidak dapat dirubah secara logis oleh orang lain. Keyakinan ini berasal dari pemikiran klien yang sudah kehilangan kontrol. Waham dipengaruhi oleh faktor pertumbuhan dan perkembangan seperti adanya penolakan, kekerasan, tidak ada kasih sayang, pertengkaran orang tua, dan aniaya (Dermawan, 2018). Gangguan proses pikir waham ini adalah gejala positif dari skizofrenia dan biasanya orang yang memiliki gejala tersebut akan melakukan hal-hal yang sesuai dengan jenis wahamnya, yaitu dengan memiliki rasa curiga yang tinggi terhadap diri sendiri maupun orang lain, merasa memiliki kekuasaan yang besar, merasa mempunyai kekuatan yang luar biasa jauh diatas 
manusia pada umumnya, merasa dirinya mempunyai penyakit yang sangat parah atau dapat menular ke orang lain, serta menganggap dirinya sudah meninggal. (Statistical, 2019).

Klien dengan gangguan jiwa sikotik, mengalami penurunan daya nilai realitas (reality testing ability). Klien tidak lagi mengenali tempat, waktu, dan orangorang di sekitarnya. Hal ini dapat mengakibatkan klien merasa asing dan menjadi pencetus terjadinya ansietas pada klien. Untuk menanggulangi kendala ini, maka perlu ada aktivitas yang memberi stimulus secara konsisten kepada klien tentang realitas di sekitarnya. Stimulus tersebut meliputi stimulus tentang realita lingkungan, yaitu diri sendiri, orang lain, waktu, dan tempat (Laily, 2016).

Dalam beberapa penelitian dijelaskan bahwa orientasi realita dapat meningkatkan fungsi perilaku. Pasien perlu dikembalikan pada realita bahwa hal-hal yang dikemukakan tidak berdasarkan fakta dan belum dapat diterima orang lain dengan tidak mendukung ataupun membantah waham. Tidak jarang dalam proses ini pasien mendapatkan konfrontasi dari lingkungan terkait pemikiran dan keyakinannya yang tidak realistis. Hal tersebut akan memicu agresifitas pasien waham. Reaksi agresif ini merupakan efek dari besarnya intensitas waham yang dialami pasien. Salah satu cara untuk mengontrol perilaku agresif dari pasien waham yaitu dengan memberi asuhan keperawatan jiwa (Keliat, 2019). Pemberian intervensi keperawatan jiwa pada pasien dengan waham berfokus pada orientasi realita, menstabilkan proses pikir, dan keamanan (Townsend, 2015).

Berdasarkan hasil survey awal yang dilakukan diruang rawat inap Gunung Sitoli terdapat 13 orang pasien yang mengalami skizofrenia dengan masalah keperawatan gangguan proses pikir: waham sebanyak 3 orang. Sehingga kelompok tertarik untuk memberikan asuhan keperawatan pada pasien dengan masalah gangguan proses pikir: waham.

\subsection{Rumusan Masalah}

Bagaimana memberikan asuhan keperawatan jiwa pada Tn.M dengan gangguan 
proses pikir: waham di ruang Gunung sitoli?

\subsection{Tujuan}

\subsubsection{Tujuan umum}

Mahasiswa mampu menerapkan asuhan keperawan jiwa pada Tn. M dengan Waham Kebesaran di Ruang Gunung sitoli.

\subsubsection{Tujuan Khusus}

Setelah melakukan asuhan keperawatan kepada klien dengan Waham Kebesaran, mahasiswa/i diharapkan mampu :

1. Mahasiswa mampu mengetahui defenisi, penyebab, tanda dan gejala, rentang respon dan penatalaksanaan pada klien Waham Kebesaran

2. Mahasiswa mampu melakukan pengkajian, analisa data pada Tn. M dengan Waham Kebesaran di Ruang Gunung sitoli.

3. Mahasiswa mampu menegakkan diagnosa keperawatan pada Tn. M dengan Waham Kebesaran di Ruang Gunung sitoli.

4. Mahasiswa mampu menetapkan intervensi keperawatan pada Tn. M dengan Waham Kebesaran di Ruang Gunung sitoli.

5. Mahasiswa mampu melakukan implementasi keperawatan pada Tn. M dengan Waham Kebesaran di Ruang Gunung sitoli.

6. Mahasiswa mampu mengevaluasi hasil asuhan keperawatan pada Tn. M dengan Waham Kebesaran di Ruang Gunung sitoli.

7. Mahasiswa mampu melakukan pendokumentasian pada Tn. M dengan Waham Kebesaran di Ruang Gunung sitoli.

\subsection{Manfaat}

\section{Pasien}

Diharapkan tindakan yang telah di ajakarkan dapat di terapkan secara mandiri untuk berpikir realitis dan untuk mendukung kelangsungan kesehatan pasien. 


\section{Keluarga}

Diharapkan keluarga dapat memberikan dukungan moral, emosional dan spiritual serta membantu dalam menerapkan asuhan keperawatan jiwa kepada pasien dengan masalah waham kebesaran

\section{Institusi Pendidikan}

Bagi institusi pendidikan diharapkan untuk menjadi acuan dalam dalam melakukan kegiatan kemahasiswaan dalam bidang keperawatan jiwa.

\section{RSJ Prof. Dr. M. Ildrem Medan}

Diharapkan dapat menjadi acuan dalam menanganin atau dalam memberikan pelayanan kepada pasien dengan gangguan jiwa dengan waham di RSJ Prof. Dr. M. Ildrem Medan. 


\section{BAB 2 \\ TINJAUAN TEORITIS}

\subsection{Konsep Waham}

\subsubsection{Definisi}

Waham adalah suatu kepercayaan yang terpaku dan tidak dapat dikoreksi atas dasar fakta dan kenyataan. Tetapi harus dipertahankan, bersifat patologis dan tidak terkait dengan kebudayaan setempat. Adanya waham menunjukkan suatu gangguan jiwa yang berat, isi waham dapat menerangkan pemahaman terhadap faktor-faktor dinamis penyebab gangguan jiwa. Terbetuknya kepercayaan yang bersifat waham adalah sebagai perlindungan diri terhadap rasa takut dan untuk pemuasan kebutuhan (Sutini dan Yosep, 2019).

Waham adalah keyakinan palsu, didasarkan kepada kesimpulan yang salah tentang eksternal, tidak sejalan dengan intelegensia pasien dan latar belakang kultural, yang tidak dapat dikoreksi dengan suatu alasan (Zukna, 2017). Waham adalah keyakinan klien yang tidak sesuai dengan kenyataan yang tetap dipertahankan dan tidak dapat dirubah secara logis oleh orang lain. Keyakinan ini berasal dari pemikiran klien yang sudah kehilangan kontrol (Rusdi, 2020).

Berdasarkan beberapa defisini diatas dapat disimpulkan bahwa waham merupakan suatu keyakinan yang salah dan dipertahankan dengan kuat oleh klien tanpa disertai bukti-bukti yang jelas.

\subsubsection{Etiologi}

Menurut WHO (2016) secara medis ada banyak kemungkinan penyebab waham, termasuk gangguan neurodegeneratif, gangguan sistem saraf pusat, penyakit pembuluh darah, penyakit menular, penyakit metabolisme, gangguan endokrin, defisiensi vitamin, pengaruh obat-obatan, racun, dan zat psikoaktif.

a. Faktor Predisposisi

1. Biologis

Pola keterlibatan keluarga relative kuat yang muncul di kaitkan dengan delusi atau waham. Dimana individu dari anggota keluarga yang di manifestasikan dengan gangguan ini berada pada resiko lebih tinggi 
untuk mengalaminya di bandingkan dengan populasi umum. Studi pada manusia kembar juga menunjukan bahwa ada keterlibatan factor (Yosep, 2019).

\section{Teori Psikososial}

a. System Keluarga

Perkembangan skizofrenia sebagai suatu perkembangan disfungsi keluarga. Konflik diantara suami istri mempengaruhi anak. Bayaknya masalah dalam keluarga akan mempengaruhi perkembangan anak dimana anak tidak mampu memenuhi tugas perkembangan dimasa dewasanya. Beberapa ahli teori menyakini bahwa individu paranoid memiliki orang tua yang dingin, perfeksionis, sering menimbulkan kemarahan, perasaan mementingkan diri sendiri yang berlebihan dan tidak percaya pada individu. Klien menjadi orang dewasa yang rentan karena pengalaman awal ini (Yosep, 2019).

\section{Teori Interpersonal}

Dikemukakan oleh Priasmoro (2018) di mana orang yang mengalami psikosis akan menghasilkan suatu hubungan orang tua-anak yang penuh dengan ansietas tinggi. Hal ini jika di pertahankan maka konsep diri anak akan mengalami ambivalen.

\section{Psikodinamika}

Perkembangan emosi terhambat karena kurangnya rangsangan atau perhatian ibu,dengan ini seorang bayi mengalami penyimpangan rasa aman dan gagal untuk membangun rasa percayanya sehingga menyebabkan munculnya ego yang rapuh karena kerusakan harga diri yang parah,perasaan kehilangan kendali,takut dan ansietas berat.Sikap curiga kepada seseorang di manifestasikan dan dapat berlanjut di sepanjang kehidupan. Proyeksi merupakan mekanisme koping paling umum yang di gunakan sebagai pertahanan melawan perasaan (Yosep, 2019).

Menurut Damayanti (2017) Faktor- faktor yang mempengaruhi terjadinya waham adalah: 
1. Gagal melalui tahapan perkembangan dengan sehat.

2. Disingkirkan oleh orang lain dan merasa kesepian

3. Hubungan yang tidak harmonis dengan orang lain

4. Perpisahan dengan orang yang di cintainya

5. Kegagalan yang sering di alami

6. Keturunan,paling sering pada kembar satu telur

7. Menggunakan penyelesaian masalah yang tidak sehat misalnya menyalahkan orang lain.

b. Faktor Presipitasi

1. Biologi

Menurut Direja (2018) Stress biologi yang berhubungan dengan respon neurologik yang maladaptif termasuk:

a) Gangguan dalam putaran umpan balik otak yang mengatur proses informasi

b) Abnormalitas pada mekanisme pintu masuk dalam otak yang mengakibatkan ketidakmampuan untuk secara selektif menanggapi rangsangan.

2. Stres lingkungan

Stres biologi menetapkan ambang toleransi terhadap stress yang berinteraksi dengan stressor lingkungan untuk menentukan terjadinya gangguan perilaku (Direja, 2018).

3. Pemicu gejala

Pemicu merupakan prekursor dan stimulus yang yang sering menunjukkan episode baru suatu penyakit. Pemicu yang biasa terdapat pada respon neurobiologik yang maladaptif berhubungan dengan kesehatan. Lingkungan, sikap dan perilaku individu (Direja, 2018) 


\subsubsection{Rentang Respon}

Menurut Darmiyanti (2016), rentang respon waham sebagai berikut :

Respon adaptif

Respon Maladaptif

\begin{tabular}{lll} 
& & \\
\multicolumn{1}{c|}{$\begin{array}{ll} \\
\text { Pikiran logis }\end{array}$} & \multicolumn{1}{c|}{ Disorientasi Pikiran } & Gg.Pikiran/Waham \\
Persepsi Akurat & \multicolumn{1}{c}{ Ilusi } & Sulit Berespon \\
Emosi Konsisten & Reaksi Emosi Ber (+/-) & Perilaku Kacau \\
Prilaku Sesuai & Prilaku Aneh/Tdk Biasa & Isolasi Sosial \\
Berhubungan Social & Menarik Diri &
\end{tabular}

\subsubsection{Fase Waham}

Menurut Eriawan (2019) Proses terjadinya waham dibagi menjadi enam yaitu:

\section{a. Fase Lack of Human need}

Waham diawali dengan terbatasnya kebutuhan-kebutuhan klien baik secara fisik maupun psikis. Secara fisik klien dengan waham dapat terjadi pada orang-orang dengan status sosial dan ekonomi sangat terbatas. Biasanya klien sangat miskin dan menderita. Keinginan ia untuk memenuhi kebutuhan hidupnya mendorongnya untuk melakukan kompensasi yang salah. Ada juga klien yang secara sosial dan ekonomi terpenuhi tetapi kesenjangan antara Reality dengan selfideal sangat tinggi. Misalnya ia seorang sarjana tetapi menginginkan dipandang sebagai seorang dianggap sangat cerdas, sangat berpengalaman dan diperhitungkan dalam kelompoknya. Waham terjadi karena sangat pentingnya pengakuan bahwa ia eksis di dunia ini. Dapat dipengaruhi juga oleh rendahnya penghargaan saat tumbuh kembang (life span history) (Eriawan, 2019).

\section{b. Fase lack of self esteem}

Tidak ada tanda pengakuan dari lingkungan dan tingginya kesenjangan antara self ideal dengan self reality (kenyataan dengan harapan) serta dorongan kebutuhan yang tidak terpenuhi sedangkan standar lingkungan sudah melampaui kemampuannya. Misalnya, saat lingkungan sudah banyak yang kaya, menggunakan teknologi komunikasi yang canggih, 
berpendidikan tinggi serta memiliki kekuasaan yang luas, seseorang tetap memasang self ideal yang melebihi lingkungan tersebut. Padahal self reality-nya sangat jauh. Dari aspek pendidikan klien, materi, pengalaman, pengaruh, support system semuanya sangat rendah (Eriawan, 2019)

\section{c. Fase control internal external}

Klien mencoba berfikir rasional bahwa apa yang ia yakini atau apaapa yang ia katakan adalah kebohongan, menutupi kekurangan dan tidak sesuai dengan kenyataan. Tetapi menghadapi kenyataan bagi klien adalah sesuatu yang sangat berat, karena kebutuhannya untuk diakui, kebutuhan untuk dianggap penting dan diterima lingkungan menjadi prioritas dalam hidupnya, karena kebutuhan tersebut belum terpenuhi sejak kecil secara optimal. Lingkungan sekitar klien mencoba memberikan koreksi bahwa sesuatu yang dikatakan klien itu tidak benar, tetapi hal ini tidak dilakukan secara adekuat karena besarnya toleransi dan keinginan menjaga perasaan. Lingkungan hanya menjadi pendengar pasif tetapi tidak mau konfrontatif berkepanjangan dengan alasan pengakuan klien tidak merugikan orang lain (Eriawan, 2019)

\section{d. Fase environment support}

Adanya beberapa orang yang mempercayai klien dalam lingkungannya menyebabkan klien merasa didukung, lama kelamaan klien menganggap sesuatu yang dikatakan tersebut sebagai suatu kebenaran karena seringnya diulang-ulang. Dari sinilah mulai terjadinya kerusakan kontrol diri dan tidak berfungsinya norma ( Super Ego ) yang ditandai dengan tidak ada lagi perasaan dosa saat berbohong (Eriawan, 2019)

\section{e. Fase comforting}

Klien merasa nyaman dengan keyakinan dan kebohongannya serta menganggap bahwa semua orang sama yaitu akan mempercayai dan mendukungnya. Keyakinan sering disertai halusinasi pada saat klien menyendiri dari lingkungannya. Selanjutnya klien lebih sering menyendiri dan menghindar interaksi sosial (Isolasi sosial) (Eriawan, 2019) 


\section{f. Fase improving}

Apabila tidak adanya konfrontasi dan upaya-upaya koreksi, setiap waktu keyakinan yang salah pada klien akan meningkat. Tema waham yang muncul sering berkaitan dengan traumatik masa lalu atau kebutuhankebutuhan yang tidak terpenuhi (rantai yang hilang). Waham bersifat menetap dan sulit untuk dikoreksi. Isi waham dapat menimbulkan ancaman diri dan orang lain. Penting sekali untuk mengguncang keyakinan klien dengan cara konfrontatif serta memperkaya keyakinan relegiusnya bahwa apaapa yang dilakukan menimbulkan dosa besar serta ada konsekuensi sosial (Eriawan, 2019).

\subsubsection{Jenis Waham}

Menurut Prakasa (2020) bahwa jenis waham yaitu :

a. Waham kebesaran: individu meyakini bahwa ia memiliki kebesaran atau kekuasaan khusus yang diucapkan berulang kali, tetapi tidak sesuai kenyataan. Misalnya, "Saya ini pejabat di separtemen kesehatan lho!" atau, "Saya punya tambang emas."

b. Waham curiga: individu meyakini bahwa ada seseorang atau kelompok yang berusaha merugikan/mencederai dirinya dan siucapkan berulang kali, tetapi tidak sesuai kenyataan.

"Saya tidak tahu seluruh saudara saya ingin menghancurkan hidup saya karena mereka iri dengan kesuksesan saya."

c. Waham agama: individu memiliki keyakinan terhadap terhadap suatu agama secara berlebihan dan diucapkan berulang kali, tetapi tidak sesuai kenyataan. Contoh, "Kalau saya mau masuk surga, saya harus menggunakan pakaian putih setiap hari."

d. Waham somatic: individu meyakini bahwa tubuh atau bagian tubuhnya terganggu atau terserang penyakit dan diucapkan berulang kali, tetapi tidak sesuai dengan kenyataan. Misalnya, "Saya sakit kanker." (Kenyataannya pada pemeriksaan laboratorium tidak ditemukan tandatanda kanker, tetapi pasien terus mengatakan bahwa ia sakit kanker). 
e. Waham nihilistik: Individu meyakini bahwa dirinya sudah tidak ada di dunia/meninggal dan diucapkan berulang kali, tetapi tidak sesuai kenyataan. Misalnya, "Ini kan alam kubur ya, semua yang ada disini adalah roh-roh".

f. Waham sisip pikir : keyakinan klien bahwa ada pikiran orang lain yang disisipkan ke dalam pikirannya.

g. Waham siar pikir : keyakinan klien bahwa orang lain mengetahui apa yang dia pikirkan walaupun ia tidak pernah menyatakan pikirannya kepada orang tersebut

h. Waham kontrol pikir : keyakinan klien bahwa pikirannya dikontrol oleh kekuatan di luar dirinya.

\subsubsection{Tanda dan Gejala}

Menurut Prakasa (2020) bahwa tanda dan gejala gangguan proses pikir waham terbagi menjadi 8 gejala yaitu, menolak makan, perawatan diri, emosi, gerakan tidak terkontrol, pembicaraan tidak sesuai, menghindar, mendominasi pembicaraan, berbicara kasar.

1. Waham Kebesaran

a. DS : Klien mengatakan bahwa ia adalah presiden, Nabi, Wali, artis dan lainnya yang tidak sesuai dengan kenyataan dirinya.

b. DO :

1) Perilaku klien tampak seperti isi wahamnya

2) Inkoheren ( gagasan satu dengan yang lain tidak logis, tidak berhubungan, secara keseluruhan tidak dapat dimengerti

3) Klien mudah marah

4) Klien mudah tersinggung

2. Waham Curiga

a. DS :

1) Klien curiga dan waspada berlebih pada orang tertentu

2) Klien mengatakan merasa diintai dan akan membahayakan dirinya. 
b. DO :

1) Klien tampak waspada

2) Klien tampak menarik diri

3) Perilaku klien tampak seperti isi wahamnya

4) Inkoheren ( gagasan satu dengan yang lain tidak logis, tidak berhubungan, secara keseluruhan tidak dapat dimengerti )

3. Waham Agama

a. DS :

Klien yakin terhadap suatu agama secara berlebihan, diucapkan berulang-ulang tetapi tidak sesuai dengan kenyataan.

b. DO :

1) Perilaku klien tampak seperti isi wahamnya

2) Klien tampak bingung karena harus melakukan isi wahamnya

3) Inkoheren (gagasan satu dengan yang lain tidak logis, tidak berhubungan, secara keseluruhan tidak dapat dimengerti)

4. Waham Somatik

a. DS :

1) Klien mengatakan merasa yakin menderita penyakit fisik

2) Klien mengatakan merasa khawatir sampai panik

b. DO :

1) Perilaku klien tampak seperti isi wahamnya

2) Inkoheren ( gagasan satu dengan yang lain tidak logis, tidak berhubungan, secara keseluruhan tidak dapat dimengerti )

3) Klien tampak bingung

4) Klien mengalami perubahan pola tidur

5) Klien kehilangan selera makan

5. Waham Nihilistik

a. DS :

Klien mengatakan bahwa dirinya sudah meninggal dunia, diucapkan berulang-ulang tetapi tidak sesuai dengan kenyataan.

b. DO :

1) Perilaku klien tampak seperti isi wahamnya 
2) Inkoheren ( gagasan satu dengan yang lain tidak logis, tidak berhubungan, secara keseluruhan tidak dapat dimengerti )

3) Klien tampak bingung

4) Klien mengalami perubahan pola tidur

5) Klien kehilangan selera makan

\section{Waham Bizzare}

a. Sisip Pikir :

1) DS :

a) Klien mengatakan ada ide pikir orang lain yang disisipkan dalam pikirannya yang disampaikan secara berulang dan tidak sesuai dengan kenyataan.

b) Klien mengatakan tidak dapat mengambil keputusan

2) $\mathrm{DO}$ :

a) Perilaku klien tampak seperti isi wahamnya

b) Klien tampak bingung

c) Inkoheren (gagasan satu dengan yang lain tidak logis, tidak berhubungan, secara keseluruhan tidak dapat dimengerti)

d) Klien mengalami perubahan pola tidur

b. Siar Pikir

DS :

a) Klien mengatakan bahwa orang lain mengetahui apa yang dia pikirkan yang dinyatakan secara berulang dan tidak sesuai dengan kenyataan.

b) Klien mengatakan merasa khawatir sampai panik

c) Klien tidak mampu mengambil keputusan

DO :

a) Klien tampak bingung

b) Perilaku klien tampak seperti isi wahamnya

c) Inkoheren (gagasan satu dengan yang lain tidak logis, tidak berhubungan, secara keseluruhan tidak dapat dimengerti)

d) Klien tampak waspada

e) Klien kehilangan selera makan 
c. Kontrol Pikir

1) DS :

a) Klien mengatakan pikirannya dikontrol dari luar

b) Klien tidak mampu mengambil keputusan

2) DO : - Perilaku klien tampak seperti isi wahamnya

a) Klien tampak bingung

b) Klien tampak menarik diri

c) Klien mudah tersinggung

d) Klien mudah marah

e) Klien tampak tidak bisa mengontrol diri sendiri

f) Klien mengalami perubahan pola tidur

g) Inkoheren (gagasan satu dengan yang lain tidak logis, tidak berhubungan, secara keseluruhan tidak dapat dimengerti)

\subsubsection{Penatalaksanaan Medis}

Menurut Prastika (2014) penatalaksanaan medis waham antara lain :

1. Psikofarmalogi

a. Litium Karbonat

Jenis litium yang paling sering digunakan untuk mengatasi gangguan bipolar, menyusul kemudian litium sitial. Litium masih efektif dalam menstabilkan suasana hati pasien dengan gangguan bipolar. Gejala hilang dalam jangka waktu 1-3 minggu setelah minum obat juga digunakan untuk mencegah atau mengurangi intensitas serangan ulang pasien bipolar dengan riwayat mania.

b. Haloperidol

Obat antipsikotik (mayor tranquiliner) pertama dari turunan butirofenon. Mekanisme kerja yang tidak diketahui. Haloperidol efektif untuk pengobatan kelainan tingkah laku berat pada anak-anak yang sering membangkang dan eksplosif. Haloperidol juga efektif untuk pengobatan jangka pendek, pada anak yang hiperaktif juga melibatkan aktivitas motorik berlebih memiliki kelainan tingkah laku seperti: Impulsif, sulit 
memusatkan perhatian, agresif, suasana hati yang labil dan tidak tahan frustasi.

c. Karbamazepin

Karbamazepin terbukti efektif, dalam pengobatan kejang psikomotor, dan neuralgia trigeminal. Karbamazepin secara kimiawi tidak berhubungan dengan obat antikonvulsan lain atau obat lain yang digunakan untuk mengobati nyeri pada neuralgia trigeminal Pasien hiperaktif atau agitasi anti psikotik potensi rendah Penatalaksanaan ini berarti mengurangi dan menghentikan agitasi untuk pengamanan pasien. Hal ini menggunakan penggunaan obat anti psikotik untuk pasien waham.

d. Antipsikosis atipikal (olanzapin, risperidone). Pilihan awal Risperidone tablet $1 \mathrm{mg}, 2 \mathrm{mg}$, $3 \mathrm{mg}$ atau Clozapine tablet $25 \mathrm{mg}$, 100mg. Keuntungan

e. Tipikal (klorpromazin, haloperidol), klorpromazin 25100mg. Efektif untuk menghilangkan gejala positif. Penarikan diri selama potensi tinggi seseorang mengalami waham. Dia cenderung menarik diri dari pergaulan dengan orang lain dan cenderung asyik dengan dunianya sendiri (khayalan dan pikirannya sendiri). Oleh karena itu, salah satu penatalaksanaan pasien waham adalah penarikan diri yang potensial, Hal ini berarti penatalaksanaannya penekanankan pada gejala dari waham itu sendiri, yaitu gejala penarikan diri yang berkaitan dengan kecanduan morfin biasanya sewaktuwaktu sebelum waktu yang berikutnya, penarikan diri dari lingkungan sosial

f. ECT tipe katatonik Electro Convulsive Therapy (ECT) adalah sebuah prosedur dimana arus listrik melewati otak untuk pelatihan kejang singkat. Hal ini menyebabkan perubahan dalam kimiawi otak yang dapat mengurangi penyakit mental tertentu, seperti skizofrenia katatonik. ECT bisa menjadi pilihan jika gejala yang parah atau jika obat-obatan tidak membantu meredakan episode katatonik.

g. Psikoterapi Walaupun obat-obatan penting untuk mengatasi pasien waham, namun psikoterapi juga penting. Psikoterapi mungkin tidak sesuai untuk semua orang, terutama jika gejala terlalu berat untuk terlibat dalam proses terapi yang memerlukan komunikasi dua arah. Yang termasuk 
dalam psikoterapi adalah terapi perilaku, terapi kelompok, terapi keluarga, terapi supportif.

\subsection{Konsep Asuhan Keperawatan Jiwa}

\subsubsection{Pengkajian}

Menurut Damaiyanti (2017) hal-hal yang harus dikaji pada klien waham adalah:

1. Identifikasi klien

Perawat yang merawat klien melakukan perkenalan dan kontrak dengan klien tentang: Nama klien, panggilan klien, Nama perawat, tujuan, waktu pertemuan, topik pembicaraan.

2. Keluhan utama/alasan masuk

Tanyakan pada keluarga/klien hal yang menyebabkan klien dan keluarga datang ke Rumah Sakit, yang telah dilakukan keluarga untuk mengatasi masalah dan perkembangan yang dicapai.

3. Tanyakan pada klien/keluarga, apakah klien pernah mengalami gangguan jiwa pada masa lalu, pernah melakukan, mengalami, penganiayaan fisik, seksual, penolakan dari lingkungan, kekerasan dalam keluarga dan tindakan kriminal. Dapat dilakukan pengkajian pada keluarga faktor yang mungkin mengakibatkan terjadinya gangguan:

a. Psikologis

Keluarga, pengasuh dan lingkungan klien sangat mempengaruhi respon psikologis dari klien.

b. Biologis

Gangguan perkembangan dan fungsi otak atau SSP, pertumbuhan dan perkembangan individu pada prenatal, neonatus dan anak-anak.

c. Sosial Budaya

Seperti kemiskinan, konflik sosial budaya (peperangan, kerusuhan, kerawanan), kehidupan yang terisolasi serta stress yang menumpuk 
4. Aspek fisik/biologis

Mengukur dan mengobservasi tanda-tanda vital: TD, nadi, suhu, pernafasan. Ukur tinggi badan dan berat badan, kalau perlu kaji fungsi organ kalau ada keluhan.

5. Aspek psikososial

a. Membuat genogram yang memuat paling sedikit tiga generasi yang dapat menggambarkan hubungan klien dan keluarga, masalah yang terkait dengan komunikasi, pengambilan keputusan dan pola asuh.

b. Konsep diri

1) Citra tubuh: mengenai persepsi klien terhadap tubuhnya, bagian yang disukai dan tidak disukai.

2) Identitas diri: status dan posisi klien sebelum dirawat, kepuasan klien terhadap status dan posisinya dan kepuasanklien sebagai laki- laki/perempuan.

3) Peran: tugas yang diemban dalam keluarga /kelompok dan masyarakat dan kemampuan klien dalam melaksanakan tugas tersebut.

4) Ideal diri: harapan terhadap tubuh, posisi, status, tugas, lingkungan dan penyakitnya.

5) Harga diri: hubungan klien dengan orang lain, penilaian dan penghargaan orang lain terhadap dirinya, biasanya terjadi pengungkapan kekecewaan terhadap dirinya sebagai wujud harga diri rendah.

c. Hubungan sosial dengan orang lain yang terdekat dalam kehidupan, kelompok yang diikuti dalam masyarakat

d. Spiritual, mengenai nilai dan keyakinan dan kegiatan ibadah.

6. Status mental 
Nilai penampilan klien rapi atau tidak, amati pembicaraan klien, aktvitas motori klien, alam perasaan klien (sedih, takut, khawatir), afek klien, interaksi selama wawancara, persepsi klien, proses pikir, isi pikir, tingkat kesadaran, memori, tingkat konsentasi dan berhitung, kemampuan penilaian dan daya tilik diri.

7. Proses pikir.

Proses pikir dalam berbicara jawaban klien kadang meloncat-loncat dari satu topik ketopik lainnya, masih ada hubungan yang tidak logis dan tidak sampai pada tujuan (flight ofideas) kadang-kadang klien mengulang pembicaraan yang sama (persevere) Masalah keperawatan: Gangguan Proses Pikir.

8. Isi Pikir

Contoh isi pikir klien saat diwawancara :

a. Klien mengatakan bahwa dirinya banyak mempunyai pacar, dan pacarnya orang kaya dan bos batu bara Masalah keperawatan : waham kebesaran.

b. Klien mengatakan alasan masuk RSJ karena sakit liver. Masalah keperawatan : waham somatik.

9. Kebutuhan Persiapan Pulang

a. Kemampuan makan klien, klien mampu menyiapkan dan membersihkan alat makan

b. Klien mampu BAB dan BAK, menggunakan dan membersihkan WC serta membersihkan dan merapikan pakaian

c. Mandi klien dengan cara berpakaian, observasi kebersihan tubuh klien.

d. Istirahat dan tidur klien, aktivitas didalam dan diluar rumah

e. Pantau penggunaan obat dan tanyakan reaksi yang dirasakan setelah minum obat.

10. Masalah psikososial dan lingkungan

Dari data keluarga atau klien mengenai masalah yang dimiliki klien.

11. Pengetahuan 
Data didapatkan melalui wawancara dengan klien kemudian tiap bagian yang dimiliki klien disimpulkan dalam masalah.

12. Aspek medic

Terapi yang diterima oleh klien: ECT, terapi antara lain seperti terapi psikomotor, terapi tingkah laku, terapi keluarga, terapi spiritual, terapi okupasi, terapi lingkungan. Rehabilitasi sebagai suatu refungsionalisasi dan perkembangan klien supaya dapat melaksanakan sosialisasi secara wajar dalam kehidupan bermasyarakat.

\subsubsection{Diagnosa Keperawatan}

Menurut Damaiyanti (2017) Masalah keperawatan yang sering muncul pada klien waham adalah: Gangguan proses pikir: waham, Kerusakan komunikasi verbal dan Harga diri rendah kronik.

\subsubsection{Rencana Keperawatan}

Rencana Keperawatan yang diberikan pada klien tidak hanya berfokus pada masalah waham sebagai diagnosa penyerta lain. Hal ini dikarenakan tindakan yang dilakukan saling berkontribusi terhadap tujuan akhir yang akan dicapai. Rencana tindakan keperawatan pada klien dengan diagnosa gangguan proses pikir : waham yaitu (Keliat, 2009) :

1. Bina hubungan saling percaya

Sebelum memulai mengkaji pasien dengan waham, saudara harus membina hubungan saling percaya terlebih dahulu agar pasien merasa aman dan nyaman saat berinteraksi dengan saudara. Tindakan yang harus saudara lakukan dalam rangka membina hubungan saling percaya adalah:

a. Mengucapkan salam terapeutik

b. Berjabat tangan

c. Menjelaskan tujuan interaksi

d. Membuat kontrak topik, waktu dan tempat setiap kali bertemu pasien. 
2. Bantu orientasi realita

a. Tidak mendukung atau membantah waham pasien

b. Yakinkan pasien berada dalam keadaan aman

c. Observasi pengaruh waham terhadap aktivitas sehari-hari

d. Jika pasien terus menerus membicarakan wahamnya dengarkan tanpa memberikan dukungan atau menyangkal sampai pasien berhenti membicarakannya

e. Berikan pujian bila penampilan dan orientasi pasien sesuai dengan realitas.

f. Diskusikan kebutuhan psikologis/emosional yang tidak terpenuhi sehingga menimbulkan kecemasan, rasa takut dan marah.

g. Tingkatkan aktivitas yang dapat memenuhi kebutuhan fisik dan emosional pasien

h. Berdikusi tentang kemampuan positif yang dimiliki

i. Bantu melakukan kemampuan yang dimiliki

j. Berdiskusi tentang obat yang diminum

k. Melatih minum obat yang benar

\subsubsection{Implementasi keperawatan}

Implementasi disesuaikan dengan rencana tindakan keperawatan. Pada situasi nyata sering pelaksanaan jauh berbeda dengan rencana hal ini terjadi karena perawat belum terbiasa menggunakan rencana tertulis dalam melaksanakan tindakan keperawatan Dalami (2019). Adapun pelaksanaan tindakan keperawatan jiwa dilakukan berdasarkan Strategi Pelaksanaan (SP) yang sesuai dengan masing-masing maslaah utama.

Pada masalah gangguan proses pikir : waham terdapat 4 macam SP yaitu :

SP 1 : Latihan orientasi realita : orientasi orang, tempat, dan waktu serta lingkungan sekitar.

SP 2 : Mengajarkan cara minum obat secara teratur

SP 3 : Melatih pemenuhan kebutuhan dasar

SP 4 : Melatih kemampuan positif yang dimiliki 


\subsubsection{Evaluasi Keperawatan}

Evaluasi adalah proses yang berkelanjutan untuk menilai efek dari tindakan keperawatan klien (Dalami, 2019). Evaluasi dilakukan terus menerus pada respon klien terhadap tindakan yang telah dilaksanakan, evaluasi dapat dibagi dua jenis yaitu : evaluasi proses atau formatif dilakukan selesai melaksanakan tindakan. Evaluasi hasil atau sumatif dilakukan dengan membandingkan respon klien pada tujuan umum dan tujuan khusus yang telah ditentukan.

Menurut Yusuf (2015) evaluasi yang diiharapkan pada asuhan keperawatan jiwa dengan gangguan proses pikir adalah:

1. Pasien mampu melakukan hal berikut:

a. Mengungkapkan keyakinannya sesuai dengan kenyataan.

b. Berkomunikasi sesuai kenyataan.

c. Menggunakan obat dengan benar dan patuh.

2. Keluarga mampu melakukan hal berikut:

a. Membantu pasien untuk mengungkapkan keyakinannya sesuai kenyataan.

b. Membantu pasien melakukan kegiatan-kegiatan sesuai dengan kemampuan dan kebutuhan pasien.

c. Membantu pasien menggunakan obat dengan benar dan patuh. 


\section{BAB 3 \\ TINJAUAN KASUS}

\subsection{Identitas Klien}

Inisial

Jenis kelamin

Umur

Agama

Status

Tanggal pengkajian

Informent
: Tn.M

: Laki-Laki

:63 Tahun

: Kristen Protestan

: Menikah

: 25 Januari 2022

: Status klien, komunikasi dengan pegawai RSJ dan komunikasi dengan klien.

\subsection{Alasan Masuk Rumah Sakit}

Alasan klien masuk RSJ Prof. Dr. M. Ildrem Medan adalah karena klien meresahkan masyarakat, bicara terus-menerus, menghancurkan barang-barang, merasa dirinya adalah calon bupati, gubernur dan merasa dirinya paling hebat.

\subsection{Faktor Predisposisi}

Klien pernah masuk RSJ sebelumnya pada tahun 2021, klien mengatakan sudah mengalami seperti ini sejak masih lajang dan sudah berulang kali diantar keluarga kerumah sakit jiwa. Klien tidak pernah mengalami penganiayaan maupun kekerasan. Klien mengatakan mempunyai 10 orang anak dan salah satu anaknya juga mengalami gangguan jiwa yang sekarang sedang dirawat di Rumah Sakit Jiwa karena membakar toliet umum. Klien mengatakan pernah ingin berkuliah dan ingin menjadi guru namun gagal. Klien juga merasa sedih karena tidak dapat menafkahi istri dan anak-anaknya, anaknya tidak dapat melanjutkan kejenjang pendidikan yang lebih tinggi karena keterbatasan biaya, ia merasa bahwa hidupnya menjadi terbengkalai. Masalah Keperawatan: Koping individu inefektif.

\subsection{Fisik}

Klien tidak memiliki keluhan fisik, saat dilakukan pemeriksaan tanda-tanda vital, didapatkan hasil TD : 150/90 mmHg ; N : 100x/i ; S : 36, $6^{\circ} \mathrm{C} ; \mathrm{P}: 22 x /$. Klien memiliki tinggi badan $170 \mathrm{~cm}$ dan berat badan $80 \mathrm{Kg}$. 


\subsection{Psikososial}

\subsubsection{Genogram}

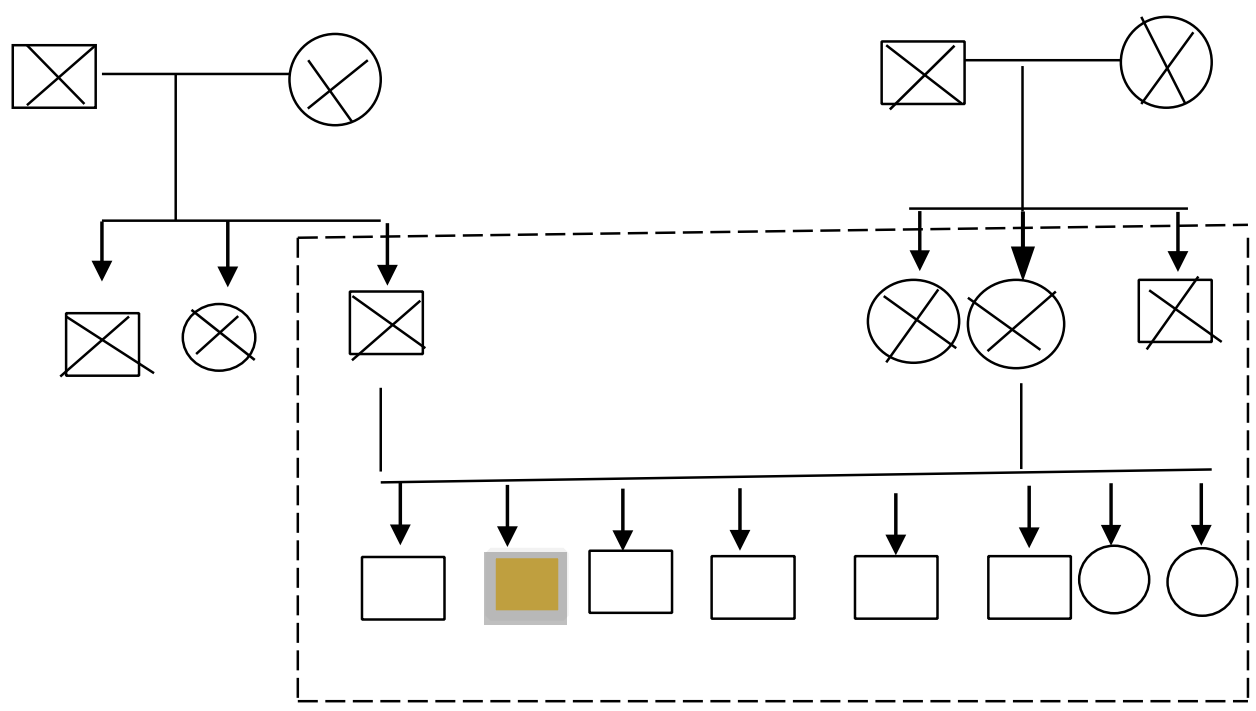

Keterangan :

$\begin{array}{ll}\square & : \text { Laki-laki } \\ & : \text { Perempuan } \\ & : \text { Klien } \\ & : \text { Tinggal dalam satu rumah } \\ & : \text { meninggal }\end{array}$

Penjelasan :

Klien merupakan anak ke 2 dari 8 bersaudara dan kedua orang tuanya sudah meninggal.

\subsubsection{Konsep diri}

a. Gambaran diri : Klien menyukai seluruh tubuhnya dan tidak ada yang cacat

b. Identitas : Klien anak ke 2 dari 8 bersaudara, klien mengetahui identitas dapat menyebutkan nama, alamat dan tanggal lahirnya.

c. Peran : Klien sadar belum memenuhi perannya sebagai anak dan orangtua

d. Ideal diri : Klien merasa malu karena tidak dapat memenuhi kebutuhan keluarga dan menjadi kepala keluarga yang baik. 
e. Harga diri : Klien mengatakan merasa malu, merasa bosan, sedih, dan tidak berguna serta tidak bisa menyenangkan orangtua, istri dan anak-anaknya. Masalah keperawatan: Gangguan konsep diri : Harga diri rendah

\subsubsection{Hubungan sosial}

Klien mengganggap bahwa keluarganya adalah orang yang sangat berarti dalam hidupnya, terutama orangtua, istri dan anak-anaknya. Klien mengikuti kegiatan di luar ruangan. Klien mengatakan mempunyai berhubungan baik dengan orang lain dan teman-temannya.

\subsubsection{Spiritual}

a. Nilai dan Keyakinan : Klien beragama Kristen Protestan, pernah masuk islam. Dan meyakini kedua agama tersebut.

b. Kegiatan Ibadah : Klien jarang beribadah tapi selalu berdoa untuk kesembuhannya.

\subsubsection{Status Mental}

1. Penampilan

Penjelasan : Klien rapi dan bersih, klien mandi 2x sehari menggunakan shampo dan sabun dan menggosok gigi nya.

2. Pembicaraan

Penjelasan : Klien saat diberikan pertanyaan kadang-kadang menjawab tidak nyambung dan merasa paling hebat, serta mengaku sebagai bupati.

Masalah keperawatan : Waham (Waham Kebesaran)

3. Aktivitas Motorik

Penjelasan : Klien tampak tegang ketika diajak berkomunikasi

Masalah keperawatan : Waham (Waham Kebesaran)

4. Alam perasaan

Penjelasan : Klien merasa malu dan tidak berguna karena tidak dapat menafkahi keluarga dan menyekolahkan anaknya ke jenjang pendidikan yang lebih tinggi. Klien sangat rindu dengan keluarganya.

Masalah keperawatan : Harga Diri Rendah 
5. Afek

Penjelasan : Afek klien datar, klien menjawab pertanyaan dari perawat dengan baik.

6. Interaksi selama wawancara

Penjelasan : selama berkomunikasi klien selalu mempertahankan bahwa dirinya adalah seorang bupati, berpendidikan tinggi, dan merasa paling hebat.

7. Persepsi

Penjelasan : Klien tidak mengalami gangguan persepsi sensori

8. Proses Pikir

Penjelasan : Klien berfikir seperti Flight of idea. Klien pada saat di ajak berbicara tidak nyambung, menjawabnya tidak tepat pada fokus pertanyaan dari pembicaraan.

Masalah keperawatan : Waham (Waham Kebesaran)

9. Isi pikir

Penjelasan : Klien mengatakan terobsesi menjadi seorang bupati dan ingin mencalonkan diri menjadi gubernur serta mengatakan berpendidikan tinggi padahal klien hanya tamat SLTA.

Masalah Keperawatan : Waham (Waham Kebesaran)

10. Tingkat kesadaran

Penjelasan :Klien tampak bingung dengan sekelilingnya karena temantemannya bukan pejabat-pejabat tinggi.

Masalah keperawatan : Waham (Waham Kebesaran)

11. Memori

Penjelasan : Klien tidak ada gangguan daya ingat. Klien mampu mengingat suatu hal.

12. Tingkat konsentrasi berhitung

Penjelasan : Klien kurang mampu berkonsentrasi dan klien mampu berhitung sederhana tanpa bantuan orang lain.

13. Kemampuan penilaian

Penjelasan : Klien mampu menilai mana yang lebih diutamakan dalam mengambil keputusan. 


\section{Daya tilik diri}

Penjelasan : Klien merasa bahwa dirinya adalah seorang bupati dan akan mencalonkan diri menjadi gubernur karena merasa pintar dan berpendidikan tinggi

Masalah keperawatan : Waham (Waham Kebesaran)

\subsection{Kebutuhan Persiapan Pulang}

1. Makan, Minum, BAB/BAK

Pasien dapat mengambil makan dan minum dan dapat kekamar mandi untuk $\mathrm{BAB} / \mathrm{BAK}$.

2. Mandi, berpakaian/berhias

Pasien mengatakan dapat mandi dan berpakaian secara mandiri

3. Istirahat dan tidur

Tidur siang lama : $13.00 \mathrm{WIB}$ s/d 13.30 WIB, tidur malam lama : 20.00 WIB s/d 05.00 WIB, kegiatan sebelum/sesudah : klien sebelum tidur rajin cuci muka/bangun tidur selalu berdoa

\subsection{Mekanisme Koping}

Klien mampu berbicara dengan orang lain dengan baik, klien juga mampu berolahraga. Pada saat diajak berbicara reaksi lambat/berlebih.

\subsection{Masalah Psikososial dan Lingkungan}

Klien mengatakan bahwa ia pernah gagal dalam mencapai cita-citanya serta pekerjaannya dan terkadang tidak mau berkomunikasi/bergaul dengan teman sekiar, asik dengan dirinya sendiri.

\subsection{Pengetahuan Kurang Tentang Gangguan Jiwa}

Klien tidak mengetahui tentang gangguan jiwa yang di alaminya dan obat yang dikonsumsinya.

\subsection{Aspek Medik}

Diagnosa medis : Skizofrenia Paranoid Terapi medis yang diberikan: 
a. Risperidon tablet $2 \mathrm{mg} 3 \times 1$

b. Clozapine tablet $3 \times 1$

\subsection{Analisis Data}

\begin{tabular}{|c|c|c|}
\hline No & Data & Masalah Keperawatan \\
\hline 1 & $\begin{array}{l}\text { Subjektif: } \\
\text { Klien mengatakan bahwa ia adalah seorang bupati, } \\
\text { calon gubernur, dan orang yang berpendidikan } \\
\text { tinggi yang tidak sesuai dengan kenyataan } \\
\text { Objektif : } \\
\text { Klien tampak bingung, banyak bicara dan hiperaktif }\end{array}$ & $\begin{array}{l}\text { Gangguan Proses Pikir : } \\
\text { Waham (Waham Kebesaran) }\end{array}$ \\
\hline 2 & $\begin{array}{l}\text { Subjektif: } \\
\text { Klien merasa malu tidak dapat memenuhi perannya } \\
\text { sebagai kepala rumah tangga karna tidak dapat } \\
\text { menafkahi keluarga serta klien merasa dibuang oleh } \\
\text { keluarganya dan merasa minder dengan orang lain. } \\
\text { Objektif: } \\
\text { Klien tampak malu, karena dirinya tidak ada } \\
\text { pekerjaan. Klien juga malu karena anaknya } \\
\text { mengalami hal serupa dengannya. }\end{array}$ & $\begin{array}{l}\text { Gangguan Konsep Diri : Harga } \\
\text { diri rendah }\end{array}$ \\
\hline 3 & $\begin{array}{l}\text { Subjektif: } \\
\text { 1. Klien mengatakan sering memarahi istri dan } \\
\text { orangtuanya dan pernah hampir memukul } \\
\text { istrinya dengan parang namun parangnya dibalik } \\
\text { dengan yang tumpul } \\
\text { 2. Klien mengatakan sering mengancam } \\
\text { orantuanya jika kemauannya tidak dituruti sedari } \\
\text { masih lajang dan mengancurkan barang. } \\
\text { 3. Klien marah jika orang lain membantah bahwa } \\
\text { dirinya seorang gubernur } \\
\text { Objektif: } \\
\text { - Klien tampak tegang } \\
\text { - Tangan sering mengepal } \\
\text { - Pandangan mata tajam }\end{array}$ & Risiko Perilaku Kekerasan \\
\hline 4 & $\begin{array}{l}\text { Subjektif: } \\
\text { 1. Klien mengatakan ia sangat menyesal kerena } \\
\text { telah membuat anaknya tidak dapat melanjutkan } \\
\text { pendidikannya yang jenjang yang lebih tinggi, }\end{array}$ & Koping individu inefektif \\
\hline
\end{tabular}




\begin{tabular}{|c|}
\hline $\begin{array}{l}\text { dan tidak memenuhi tanggung jawab sebagai } \\
\text { seorang ayah karena tidak bekerja } \\
\text { 2. Klien sedih karena klien berfikir bahwa orang } \\
\text { tua nya menjadi sakit dan meninggal karena } \\
\text { memikirkan kelakuannya yang tidak benar. }\end{array}$ \\
\hline $\begin{array}{l}\text { Objektif: } \\
\text { Klien tampak sedih }\end{array}$ \\
\hline
\end{tabular}

\title{
3.12 Diagnosa Keperawatan
}

a. Gangguan Proses Pikir : Waham (Waham Kebesaran)

b. Gangguan Konsep Diri : Harga Diri Rendah

c. Risiko Perilaku Kekerasan

d. Koping Individu Inefektif

\subsection{Pohon Masalah}

\author{
Risiko Perilaku Kekerasan \\ 个 \\ Perubahan proses pikir: Waham \\ 仓
}

Gangguan Konsep Diri : Harga Diri Rendah Kronis

仓

Koping Individu Inefektif 


\subsection{Intervensi Keperawatan}

\begin{tabular}{|c|c|c|}
\hline No & osa & Inter \\
\hline 1 & $\begin{array}{l}\text { Gangguan Proses Pikir : } \\
\text { Waham (Waham Kebesaram) } \\
\text { Subjektif : } \\
\text { Klien mengatakan bahwa ia } \\
\text { adalah bupati dan calon } \\
\text { gubernur yang tidak sesuai } \\
\text { dengan kenyataan } \\
\text { Objektif : } \\
\text { Klien tampak bingung, banyak } \\
\text { bicara dan hiperaktif }\end{array}$ & $\begin{array}{l}\text { Sp1: } \\
\text { Latihan orientasi realita : orientasi orang, } \\
\text { tempat, dan waktu serta lingkungan sekitar } \\
\text { Sp2: } \\
\text { Minum obat secara teratur } \\
\text { Sp 3: } \\
\text { Melatih cara pemenuhan kebutuhan } \\
\text { dasar } \\
\text { Sp 4: } \\
\text { Melatih kemampuan positif yang dimiliki }\end{array}$ \\
\hline 2 & 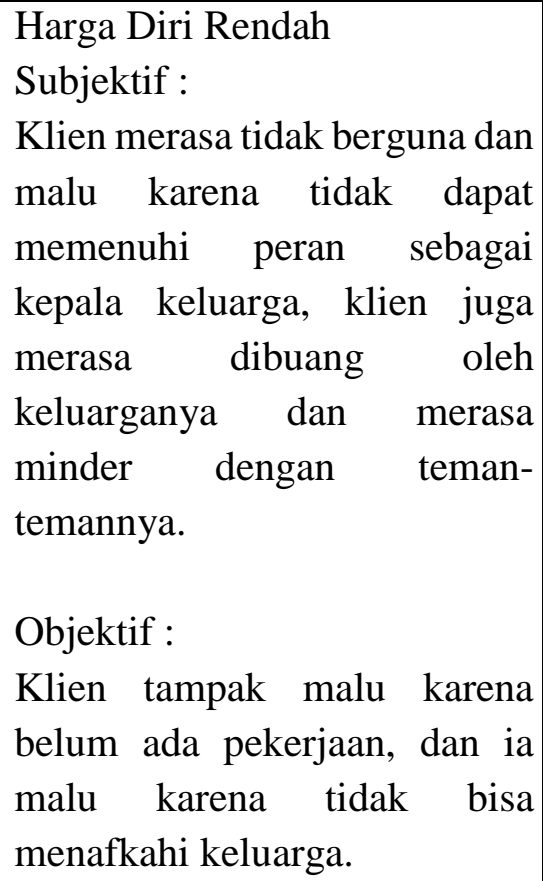 & $\begin{array}{l}\text { Sp1: } \\
\text { Mengidentifikasi kemampuan dan aspek } \\
\text { positif yang dimiliki oleh pasien } \\
\text { Sp 2: } \\
\text { 1. Menilai kemampuan yang dapat } \\
\quad \text { digunakan } \\
\text { 2. Menetapkan / memilih kegiatan sesuai } \\
\quad \text { kemampuan } \\
\text { 3. Melatih kegiatan sesuai kemampuan } \\
\quad \text { yang dipilih } 2 \\
\text { Sp 3: } \\
\text { Melatih kegiatan sesuai kemampuan yang } \\
\text { dipilih } 2 \\
\text { Sp 4: } \\
\text { Melatih kegiatan sesuai kemampuan yang } \\
\text { dipilih } 3\end{array}$ \\
\hline 3 & $\begin{array}{l}\text { Resiko Perilaku Kekerasan } \\
\text { Subjektif : } \\
\text { Klien mengatakan pernah } \\
\text { melempar barang-barang yang } \\
\text { ada dirumahnya, pernah } \\
\text { hampir memukul istrinya } \\
\text { dengan parang tumpul dan } \\
\text { marah-marah jika keinginanya } \\
\text { tidak diturutin. } \\
\text { Objektif : } \\
\text { Klien tampak memandang } \\
\text { orang lain dengan tatapan }\end{array}$ & $\begin{array}{l}\text { Sp1: } \\
\text { 1. Identifikasi penyebab, frekuensi perilaku } \\
\text { kekerasan } \\
\text { 2. Mengontrol perilaku kekerasan dengan } \\
\quad \text { tarik nafas dalam dan pukul } \\
\quad \text { kasur/bantal } \\
\text { Sp2: } \\
\text { Kontrol perilaku kekerasan dengan } \\
\text { minum obat secara teratur } \\
\text { Sp 3: } \\
\text { Kontrol perilaku kekerasan dengan } \\
\text { berbicara baik-baik }\end{array}$ \\
\hline
\end{tabular}




\begin{tabular}{|l|lr|l|}
\hline $\begin{array}{l}\text { bermusuhan dan tampak } \\
\text { gelisah. }\end{array}$ & $\begin{array}{l}\text { Sp 4: } \\
\text { Spiritual }\end{array}$ \\
\hline
\end{tabular}

3.15 Implementasi Dan Evaluasi Keperawatan

\begin{tabular}{|c|c|c|}
\hline Hari/tgl & Implementasi & Evaluasi \\
\hline \begin{tabular}{|l|} 
Senin/ \\
24-01-2022 \\
Pukul: 14.00
\end{tabular} & $\begin{array}{l}\text { 1. Data: } \\
\text { Klien merasa tidak berguna, merasa } \\
\text { dibuang oleh keluarganya dan } \\
\text { merasa bersalah karena tidak dapat } \\
\text { memenuhi sebagai kepala rumah } \\
\text { tangga. } \\
\text { Kemampuan: merapikan ruangan } \\
\text { 2. Diagnosa Keperawatan: } \\
\text { Harga diri rendah } \\
\text { 3. Tindakan Keperawatan: } \\
\text { Sp1 HDR: } \\
\text { Mengidentifikasi kemampuan dan } \\
\text { aspek positif yang dimiliki pasien } \\
\text { 4. RTL } \\
\text { Sp } 2 \text { Harga Diri Rendah: } \\
\text { a. Menilai kemampuan yang dapat } \\
\text { digunakan } \\
\text { b. Menetapkan/memilih kegiatan } \\
\text { sesuai kemampuan } \\
\text { c. Melatih kegiatan sesuai } \\
\text { kemampuan yang di pilih } 1\end{array}$ & $\begin{array}{l}\text { S: } \text { Senang } \\
\text { O: } \\
\text { Klien mampu } \\
\text { mengidentifikasi aspek positif } \\
\text { yang dimiliki pasien yaitu } \\
\text { menyapu dengan mandiri } \\
\text { A : Harga Diri Rendah (+) } \\
\text { P : } \\
\text { Mengidentifikasi kemampuan } \\
\text { dan aspek positif yang dimiliki } \\
\text { pasien: menyapu } 2 \mathrm{x} / \mathrm{hari}\end{array}$ \\
\hline \begin{tabular}{|l|} 
Selasa/ \\
25-01-2022 \\
Pukul: 14.00
\end{tabular} & $\begin{array}{l}\text { 1. Data: } \\
\text { Klien merasa tidak berguna, merasa } \\
\text { dibuang oleh keluarganya dan } \\
\text { merasa bersalah karena tidak dapat } \\
\text { memenuhi sebagai kepala rumah } \\
\text { tangga. } \\
\text { Kemampuan: merapikan ruangan } \\
\text { 2. Diagnosa Keperawatan: } \\
\text { Harga diri rendah } \\
\text { 3. Tindakan Keperawatan: } \\
\text { Sp } 2 \text { HDR: } \\
\text { a. Menilai kemampuan yang dapat } \\
\text { digunakan } \\
\text { b. Menetapkan/memilih kegiatan } \\
\text { sesuai kemampuan }\end{array}$ & 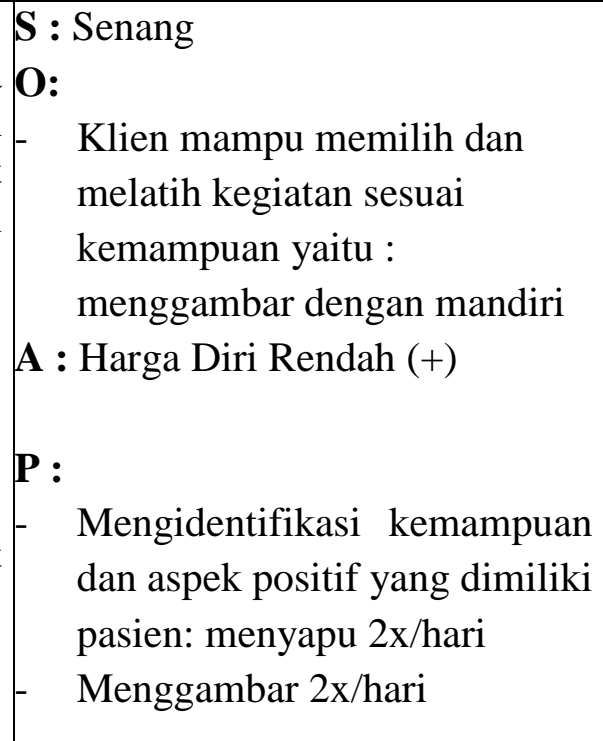 \\
\hline
\end{tabular}




\begin{tabular}{|c|c|c|}
\hline & $\begin{array}{l}\text { c. Melatih kegiatan sesuai } \\
\text { kemampuan yang di pilih } 1 \\
\text { 4. RTL } \\
\text { Sp 3: melatih kegiatan sesuai } \\
\text { kemampuan yang di pilih } 2\end{array}$ & \\
\hline $\begin{array}{l}\text { Rabu/ } \\
\text { 26-01-2022 } \\
\text { Pukul 14.30 }\end{array}$ & $\begin{array}{l}\text { 1. Data: } \\
\text { Klien merasa tidak berguna, merasa } \\
\text { dibuang oleh keluarganyadan } \\
\text { merasa bersalah karena tidak dapat } \\
\text { memenuhi sebagai kepala rumah } \\
\text { tangga. } \\
\text { Kemampuan: merapikan ruangan } \\
\text { 2. Diagnosa Keperawatan: } \\
\text { Harga diri rendah } \\
\text { 3. Tindakan Keperawatan: } \\
\text { Sp 3 HDR: } \\
\text { Melatih kegiatan sesuai kemampuan } \\
\text { yang di pilih } 2 \\
\text { 4. RTL: } \\
\text { Sp 4: Melatih kegiatan sesuai } \\
\text { kemampuan yang di pilih } 3\end{array}$ & $\begin{array}{l}\text { S : Senang } \\
\text { O: } \\
\quad \text { Klien mampu memilih dan } \\
\text { melatih kegiatan sesuai } \\
\text { kemampuan yaitu : } \\
\text { membersihkan tempat tidur } \\
\text { dengan mandiri } \\
\text { A : Harga Diri Rendah (+) } \\
\mathbf{P}: \\
\quad \text { Mengidentifikasi kemampuan } \\
\text { dan aspek positif yang dimiliki } \\
\text { pasien: menyapu 2x/hari } \\
\text { - Menggambar 2x/hari } \\
\text { - } \\
\text { Membersihkan tempat tidur } \\
\text { 2x/perhari }\end{array}$ \\
\hline $\begin{array}{l}\text { Kamis/ } \\
\text { 27-01-2022 } \\
\text { Pukul } 15.00\end{array}$ & $\begin{array}{l}\text { 1. Data: } \\
\text { Klien merasa tidak berguna, merasa } \\
\text { dibuang oleh keluarganyadan } \\
\text { merasa bersalah karena tidak dapat } \\
\text { memenuhi sebagai kepala rumah } \\
\text { tangga. } \\
\text { Kemampuan: merapikan ruangan } \\
\text { 2. Diagnosa Keperawatan: } \\
\text { Harga diri rendah } \\
\text { 3. Tindakan Keperawatan: } \\
\text { Sp } 4 \text { HDR: } \\
\text { Mengevaluasi kemampuan pasien } \\
\text { membersihkan tempat tidur } \\
\text { Melatih kegiatan sesuai kemampuan } \\
\text { yang di pilih } 3 \\
\text { 4. RTL: } \\
\text { Harga diri rendah : follow up dan } \\
\text { evaluasi Sp } 1 \text { - Sp } 4\end{array}$ & $\begin{array}{l}\text { S : } \text { Senang } \\
\text { O: } \\
\text { Klien mampu memilih dan } \\
\text { melatih kegiatan sesuai } \\
\text { kemampuan yaitu : menyuci } \\
\text { piring dengan mandiri } \\
\text { A : Harga Diri Rendah (+) } \\
\text { P : } \\
\text { Mengidentifikasi kemampuan } \\
\text { dan aspek positif yang dimiliki } \\
\text { pasien: menyapu 2x/hari } \\
\text { - Menggambar 2x/hari } \\
\text { - } \quad \text { Membersihkan tempat tidur } \\
\text { 2x/perhari } \\
\text { Menyuci piring 2x/perhari }\end{array}$ \\
\hline $\begin{array}{l}\text { Jum'at/ } \\
\text { 28-01-2022 } \\
\text { Pukul } 15.00\end{array}$ & $\begin{array}{l}\text { 1. Data: } \\
\text { Klien merasa tidak berguna, merasa } \\
\text { dibuang oleh keluarganyadan }\end{array}$ & $\begin{array}{l}\text { S: Senang dan antusias } \\
\text { O: } \\
-\quad \text { Klien mampu menyapu }\end{array}$ \\
\hline
\end{tabular}




\begin{tabular}{|c|c|c|}
\hline & $\begin{array}{l}\text { merasa bersalah karena tidak dapat } \\
\text { memenuhi sebagai kepala rumah } \\
\text { tangga. } \\
\text { Kemampuan: merapikan ruangan } \\
\text { 2. Diagnosa Keperawatan: } \\
\text { Harga diri rendah } \\
\text { 3. Tindakan Keperawatan: } \\
\text { Sp HDR: } \\
\text { Evaluasi Sp1-Sp4 }\end{array}$ & $\begin{array}{l}\text { Klien mampu menggambar } \\
\text { Klien mampu membersihkan } \\
\text { tempat tidur } \\
\text { Klien mampu menyuci piring } \\
\text { dengan mandiri } \\
\text { A : Harga Diri Rendah (-) } \\
\text { P : } \\
\text { - Mengidentifikasi kemampuan } \\
\text { dan aspek positif yang dimiliki } \\
\text { pasien: menyapu 2x/hari } \\
\text { - Menggambar 2x/hari } \\
\text { - Membersihkan tempat tidur } \\
\text { 2x/perhari } \\
\text { - Menyuci piring 2x/perhari }\end{array}$ \\
\hline $\begin{array}{l}\text { Senin/ } \\
\text { 31-01-2022 } \\
\text { Pukul: } \\
09.00\end{array}$ & 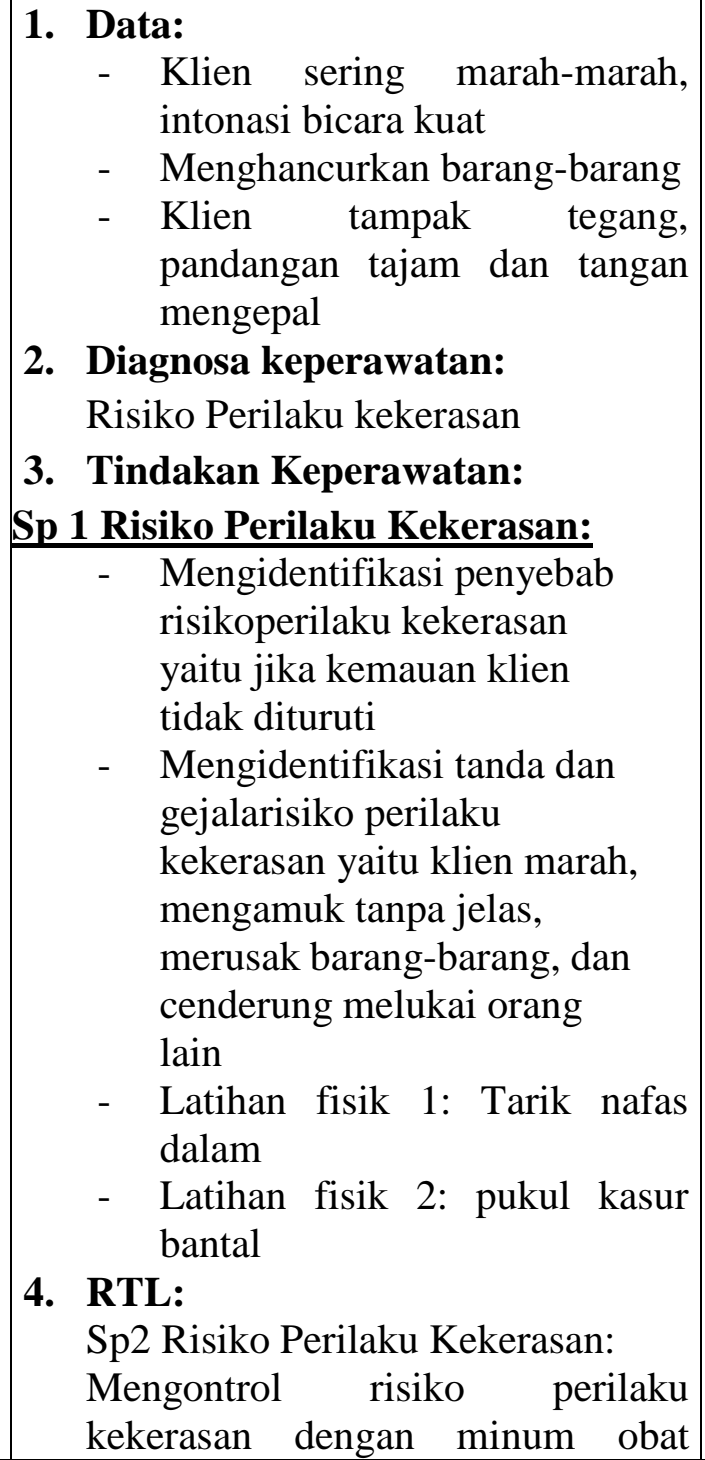 & $\begin{array}{ll}\text { S : } & \text { antusias dan bersemangat } \\
\text { O : } & \text { Klien mampu } \\
& \text { melakukan latihan fisik } \\
& \text { tarik nafas dalam } \\
& \text { dengan mandiri } \\
- & \text { Klien mampu pukul } \\
& \text { kasur bantal dengan } \\
& \text { mandiri dengan mandiri } \\
\text { A : } & \text { Risiko Perilaku kekerasan } \\
(+) & \\
\text { P : } & \text { Latihan fisik : } \\
& \text { - Tarik nafas dalam 1x/ } \\
& \text { hari } \\
\text { - Pukul kasur bantal 1x/ } & \text { hari }\end{array}$ \\
\hline
\end{tabular}




\begin{tabular}{|c|c|c|}
\hline & secara teratur & \\
\hline $\begin{array}{l}\text { Rabu/ } \\
\text { 02-02-2022 } \\
\text { Pukul: } \\
09.00\end{array}$ & $\begin{array}{l}\text { 1. Data: } \\
-\quad \text { Klien sering marah-marah, } \\
\text { intonasi bicara kuat } \\
\text { - } \text { Menghancurkan barang-barang } \\
\text { - } \text { Klien tampak tegang, } \\
\text { pandangan tajam dan tangan } \\
\text { mengepal } \\
\text { 2. Diagnosa keperawatan: } \\
\text { Risiko Perilaku kekerasan } \\
\text { 3. Tindakan Keperawatan: } \\
\text { Sp 2 Risiko Perilaku Kekerasan } \\
\text { 1. Mengevaluasi kemampuan } \\
\text { klien untuk tarik nafas } \\
\text { dalamdan pukul kasur } \\
\text { bantal } \\
\text { 2. Memberikan informasi } \\
\text { tentangpenggunaan obat } \\
\text { 4. RTL: } \\
\text { Sp } 3 \text { Risiko Perilaku Kekerasan } \\
\text { Komunikasi secara verbal: Asertif/ } \\
\text { bicara baik-baik. }\end{array}$ & $\begin{array}{ll}\text { S : } & \text { senang dan antusias } \\
\text { O : } & \text { Klien mampu } \\
- & \text { melakukan tarik nafas } \\
& \text { dalam dengan mandiri } \\
\text { - } & \text { Klin mampu pukul kasur } \\
& \text { bantal secara mandiri } \\
- & \text { Klien mampu ke poli jika } \\
& \text { merasa kumat dan } \\
& \text { meminum obat secara } \\
& \text { teratur dengan bantuan } \\
& \text { perawat dengan mandiri } \\
\text { A : } & \text { Risiko Perilaku kekerasan } \\
(+) & \\
\text { P : } & \\
\text { - } & \text { Latihan tarik nafas } \\
& \text { dalam1 x/hari } \\
\text { - } & \text { Latihan pukul kasur } \\
& \text { bantal 1 x/hari } \\
\text { - } & \text { Minum obat } \\
& \text { Clozapine 1x1 } \\
\text { - } & \text { Risperidone } 2 x 1\end{array}$ \\
\hline $\begin{array}{l}\text { Kamis/ } \\
\text { 03-02-2022 } \\
\text { Pukul: } \\
10.00\end{array}$ & $\begin{array}{l}\text { 1. Data: } \\
\text { - Klien sering marah-marah, } \\
\text { intonasi bicara kuat } \\
\text { - Menghancurkan barang-barang } \\
\text { - Klien tampak tegang, } \\
\text { pandangan tajam dan tangan } \\
\text { mengepal } \\
\text { 2. Diagnosa keperawatan: } \\
\text { Risiko Perilaku kekerasan } \\
\text { 3. Tindakan Keperawatan: } \\
\text { Sp 3 Risiko Perilaku Kekerasan } \\
\text { 1. Mengevaluasi pengetahuan } \\
\quad \text { klien tentang obat } \\
\text { 2. Komunikasi secara verbal : } \\
\text { Asertif/bicara baik-baik } \\
\text { 4. RTL: } \\
\text { Sp 4 Risiko Perilaku Kekerasan: } \\
\text { Spiritual }\end{array}$ & $\begin{array}{l}\text { S : senang dan antusias } \\
\text { O : } \\
\text { Klien mengetahui manfaat } \\
\text { obat dan minum obat } \\
\text { secara teratur } \\
\text { Klien mampu bicara baik-baik } \\
\text { dengan mandiri } \\
\text { A : Risiko Perilaku kekerasan } \\
(+) \\
\text { P : } \\
\text { Latihan tarik nafas dalam } 1 \\
\text { x/hari } \\
\text { Latihan pukul kasur } \\
\text { bantal } 1 \text { x/hari } \\
\text { Minum obat } \\
\text { - Clozapine } 1 \times 1 \\
\text { - Risperidone } 2 \times 1\end{array}$ \\
\hline
\end{tabular}




\begin{tabular}{|c|c|c|}
\hline $\begin{array}{l}\text { Jum'at/ } \\
\text { 04-02-2022 } \\
\text { Pukul: } \\
10.00\end{array}$ & $\begin{array}{l}\text { 1. Data: } \\
\text { - Klien sering marah-marah, } \\
\text { intonasi bicara kuat } \\
\text { - Menghancurkan barang-barang } \\
\text { - Klien tampak tegang, } \\
\text { pandangan tajam dan tangan } \\
\text { mengepal } \\
\text { 2. Diagnosa keperawatan: } \\
\text { Risiko Perilaku kekerasan } \\
\text { 3. Tindakan Keperawatan: } \\
\text { Sp 4 Risiko Perilaku Kekerasan } \\
\text { 1. Mengevaluasi cara bicara } \\
\text { klien } \\
\text { 2. Melatih spiritual } \\
\text { 4. RTL: } \\
\text { Evaluasi Sp1-Sp4 }\end{array}$ & 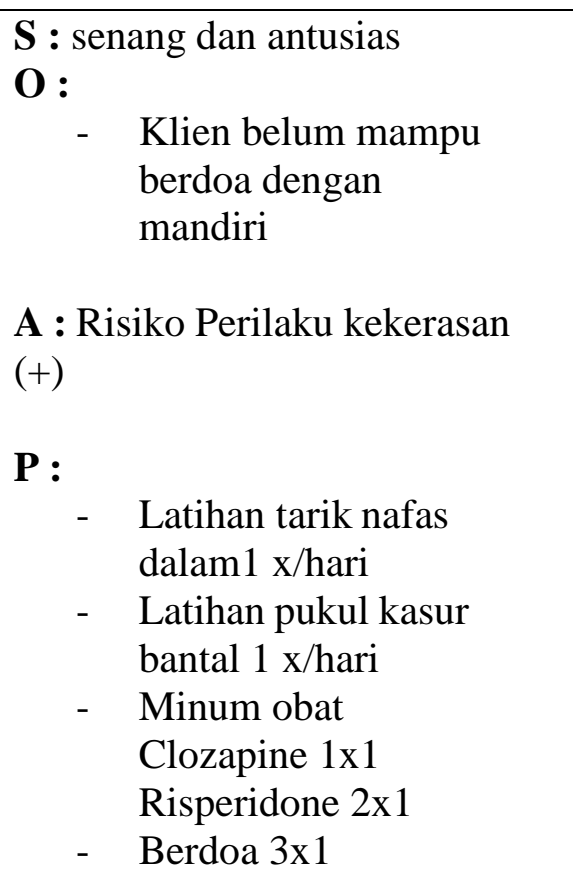 \\
\hline $\begin{array}{l}\text { Sabtu/ } \\
\text { 05-02-2022 } \\
\text { Pukul: } \\
10.00\end{array}$ & $\begin{array}{l}\text { 1. Data: } \\
\text { - Klien sering marah-marah, } \\
\text { intonasi bicara kuat } \\
\text { - Menghancurkan barang-barang } \\
\text { - Klien tampak tegang, } \\
\text { pandangan tajam dan tangan } \\
\text { mengepal } \\
\text { 2. Diagnosa keperawatan: } \\
\text { Risiko Perilaku kekerasan } \\
\text { 3. Tindakan Keperawatan: } \\
\text { Sp Risiko Perilaku Kekerasan } \\
\text { Evaluasi Sp1-Sp4 }\end{array}$ & $\begin{array}{ll}\text { S : } & \text { senang dan antusias } \\
\text { O : } & \text { Klien mampu } \\
& \text { melakukan latihan fisik } \\
& \text { tarik nafas dalam } \\
& \text { dengan mandiri } \\
\text { - } & \text { Klien mampu pukul } \\
& \text { kasur bantal dengan } \\
& \text { mandiri } \\
\text { - } & \text { Klien mengetahui } \\
& \text { manfaat obat dan } \\
& \text { minum obat secara } \\
& \text { teratur } \\
\text { - } & \text { Klien mampu bicara } \\
& \text { baik-baik } \\
\text { - } & \text { Klien mampu berdoa } \\
& \text { dengan mandiri } \\
\text { A : } & \text { Risiko Perilaku kekerasan } \\
(-) & \\
& \\
\text { P : } & \text { Latihan tarik nafas } \\
\text { - } & \text { Lalam1 x/hari } \\
\text { - } & \text { Latihan pukul kasur } \\
\end{array}$ \\
\hline
\end{tabular}




\begin{tabular}{|c|c|c|}
\hline & & $\begin{array}{ll}\text { bantal } 1 \mathrm{x} / \mathrm{hari} \\
\text { - } & \text { Minum obat } \\
\text { Clozapine } 1 \mathrm{x} 1 \\
\text { Risperidone } 2 \mathrm{x} 1 \\
\text { - } & \text { Berdoa } 3 \times 1\end{array}$ \\
\hline $\begin{array}{l}\text { Senin } \\
\text { 07/02/2022 } \\
\text { Pukul } \\
\text { 15:00 WIB }\end{array}$ & $\begin{array}{l}\text { 1. Data : } \\
\text { Tanda dan gejala : banyak } \\
\text { berbicara, hiperaktif, wajah } \\
\text { tegang, bingung, inkoheren, flight } \\
\text { of idea. Selalu menganggap } \\
\text { dirinya gubernur dan calon bupati } \\
\text { 2. Diagnosa Keperawatan } \\
\text { Waham Kebesaran } \\
\text { 3. Tindakan keperawatan: } \\
\text { Sp } 1 \text { Waham : } \\
\text { Mengidentifikasi penyebab, tanda } \\
\text { dan gejala, serta akibat dari waham } \\
\text { Menjelaskan cara mengendalikan } \\
\text { waham dengan orientasi realita: } \\
\text { panggil nama, orientasi waktu, orang } \\
\text { dan tempat/lingkungan. } \\
\text { Melatih klien orientasi realita : } \\
\text { panggil nama, orientasi waktu, orang } \\
\text { dan tempat/lingkungan } \\
\text { 4. RTL : } \\
\text { Sp 2 : minum obat secara teratur }\end{array}$ & $\begin{array}{l}\text { S : Senang } \\
\text { O : } \\
\text { - } \text { Klien mampu melakukan } \\
\text { latihan orientasi realita : } \\
\text { menyebutkan nama, waktu, } \\
\text { orang dan tempat/lingkungan } \\
\text { dengan mandiri } \\
\text { A : Waham (+) } \\
\text { P : Latihan : } \\
\quad \text { Orientasi realita : panggil } \\
\quad \text { nama, orientasi waktu, } \\
\text { orang dan } \\
\text { tempat/lingkungan 2x/hari }\end{array}$ \\
\hline
\end{tabular}




\begin{tabular}{|c|c|c|}
\hline $\begin{array}{l}\text { Selasa/ } \\
\text { 08-02-2022 } \\
\text { Pukul 14.30 }\end{array}$ & $\begin{array}{l}\text { 1. Data } \\
\text { banyak berbicara, hiperaktif, , } \\
\text { bingung, flight of idea. Selalu } \\
\text { menganggap dirinya gubernur dan } \\
\text { merasa paling hebat. } \\
\text { 2. Diagnosa keperawatan: } \\
\text { Waham kebesaran } \\
\text { 3. Tindakan keperawatan } \\
\text { Sp } 2 \text { Waham : } \\
\text { Minum obat secara teratur } \\
\text { Menjelaskan tentang obat yang } \\
\text { diminum (6 benar) } \\
\text { Mendiskusikan manfaat minum obat } \\
\text { dan kerugian tidak minum obat } \\
\text { dengan klien } \\
\text { Melatih klien cara minum obat } \\
\text { secara teratur } \\
\text { 4. RTL: } \\
\text { Sp 3: Melatih pemenuhan } \\
\text { kebutuhan dasar }\end{array}$ & $\begin{array}{l}\text { S : Senang } \\
\text { O : } \\
\text { - Klien mampu mimum obat secara } \\
\text { teratur dan mampu menyebutkan } \\
\text { manfaat dari obat yang di minum } \\
\text { dan waktu minum obat dengan } \\
\text { mandiri. } \\
\text { A : Waham (+) } \\
\text { P : Latihan : } \\
\text { - Orientasi realita : panggil } \\
\quad \text { nama, orientasi waktu, } \\
\quad \text { orang dan } \\
\quad \text { tempat/lingkungan } 2 \times / h a r i \\
\text { - Minum obat } \\
\text { Risperidon } 2 \text { mg (2x1) } \\
\text { Clozapin } 25 \text { mg }(2 \times 1)\end{array}$ \\
\hline $\begin{array}{l}\text { Rabu/ } \\
\text { 09-02-2022 } \\
\text { Pukul 14.30 }\end{array}$ & $\begin{array}{l}\text { 1. Data } \\
\text { banyak berbicara, hiperaktif, , } \\
\text { bingung, flight of idea. Selalu } \\
\text { menganggap dirinya gubernur dan } \\
\text { merasa paling hebat. } \\
\text { 2. Diagnosa keperawatan: } \\
\text { Waham kebesaran: } \\
\text { 3. Tindakan keperawatan: } \\
\text { Sp } 3 \text { Waham } \\
\text { 1. Menjelaskan cara memenuhi } \\
\text { kebutuhan klien yang tidak } \\
\text { terpenuhi akibat wahamnya } \\
\text { dan kemampuan memenuhi } \\
\text { kebutuhannya } \\
\text { 2. Melatih cara memenuhi } \\
\text { kebutuhan dasar klien yang } \\
\text { tidak terpenuhi akibat } \\
\text { wahamnya dan kemampuan } \\
\text { memenuhi kebutuhannya: } \\
\text { mandi, makan/minum } \\
\text { RTL } \\
\text { Sp 4: Melatih kemampuan positif } \\
\text { yang dimiliki pasien }\end{array}$ & $\begin{array}{l}\text { S : Senang } \\
\text { O : } \\
\text { pemenuhan dasar mandi, makan/ } \\
\text { minum secara mandiri } \\
\text { A : Waham (+) } \\
\text { P : Latihan: } \\
\text { - Orientasi realita : panggil } \\
\text { nama, orientasi waktu, } \\
\text { orang dan } \\
\text { tempat/lingkungan. } \\
\text { Minum obat } \\
\text { Risperidon 2 mg (2x1) } \\
\text { Clozapin 25 mg (2x1) } \\
\text { Latihan: } \\
\text { - Makan 3xsehari } \\
\text { - Mandi 2xsehari } \\
\text { - Olahraga setiap pagi }\end{array}$ \\
\hline
\end{tabular}




\begin{tabular}{|c|c|c|}
\hline $\begin{array}{l}\text { Senin / } \\
\text { 14-02-2022 } \\
\text { Pukul 15.00 }\end{array}$ & $\begin{array}{l}\text { 1. Data } \\
\text { banyak berbicara, hiperaktif, , } \\
\text { bingung, flight of idea. Selalu } \\
\text { menganggap dirinya gubernur dan } \\
\text { merasa paling hebat. } \\
\text { 2. Diagnosa keperawatan: } \\
\text { Waham Kebesaran } \\
\text { 3. Tindakan keperawatan: } \\
\text { Sp } 4 \text { Waham } \\
\text { - Menjelaskan kemampuan } \\
\text { positif yang dimiliki klien } \\
\text { - Mendiskusikan kemampuan } \\
\text { positif yang dimiliki klien } \\
\text { - Melatih kemampuan positif yang } \\
\text { dipilih } \\
\text { 4. RTL: } \\
\text { Waham : Follow up dan evaluasi } \\
\text { SP 1-4 Waham }\end{array}$ & $\begin{array}{l}\text { S : Senang } \\
\text { O : } \\
\text { kemampuan positif yang dimiliki } \\
\text { dengan mandiri } \\
\text { - Menggambar } \\
\text { - Menyanyi } \\
\text { - Membersihkan ruangan } \\
\text { A : Waham (+) } \\
\text { P : Latihan : } \\
\text { - Orientasi realita : panggil } \\
\text { nama, orientasi waktu, } \\
\text { orang } \\
\text { tempat/lingkungan. } \\
\text { - Minum obat: } \\
\quad \text { Risperidon 2 mg (2x1) } \\
\text { Clozapin 25 mg (2x1) } \\
\text { - Mandi 2x/hari } \\
\text { - Makan/minum 3x/hari } \\
\text { - Menggambar 1x/hari } \\
\text { - Membersihkan ruangan } \\
\text { 3x/hari }\end{array}$ \\
\hline $\begin{array}{l}\text { Selasa / } \\
\text { 15-02-2022 } \\
\text { Pukul 15.00 }\end{array}$ & $\begin{array}{l}\text { 1. Data } \\
\text { banyak berbicara, hiperaktif, , } \\
\text { bingung, flight of idea. Selalu } \\
\text { menganggap dirinya gubernur dan } \\
\text { merasa paling hebat. } \\
\text { Diagnosa keperawatan: } \\
\text { Waham Kebesaran } \\
\text { 2. Tindakan keperawatan: } \\
\text { Sp Waham } \\
\text { Evaluasi Sp 1-Sp } 4\end{array}$ & $\begin{array}{ll}\text { S : Senang } \\
\text { O : } & \\
\text { - } & \text { Klien mampu melakukan } \\
& \text { latihan orientasi realita : } \\
& \text { menyebutkan nama, } \\
& \text { waktu, orang dan } \\
& \text { tempat/lingkungan dengan } \\
& \text { mandiri } \\
\text { - } & \text { Klien mampu mimum obat } \\
& \text { secara teratur dan mampu } \\
& \text { menyebutkan manfaat dari } \\
& \text { obat yang di minum dan } \\
& \text { waktu minum obat dengan } \\
& \text { mandiri. } \\
\text { Klien mampu melakukan } \\
\text { pemenuhan dasar mandi, } \\
\text { makan/ minum secara } \\
\text { mandiri } \\
\text { Klien mampu melakukan } \\
\text { kemampuan positif yang } \\
\text { dimiliki dengan mandiri }\end{array}$ \\
\hline
\end{tabular}




\begin{tabular}{|c|c|c|}
\hline & 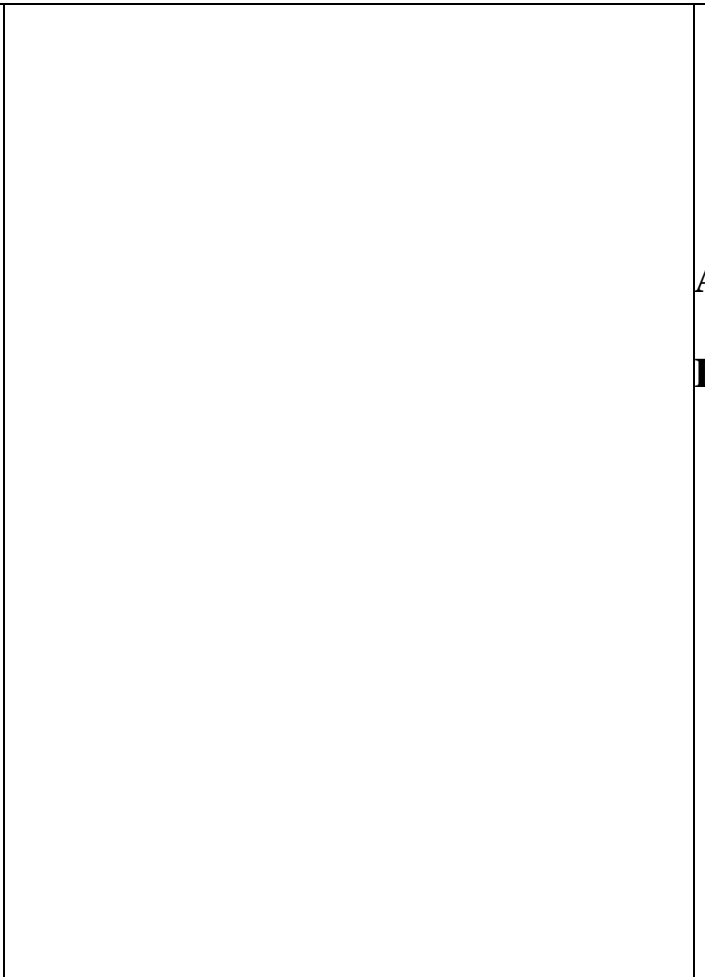 & 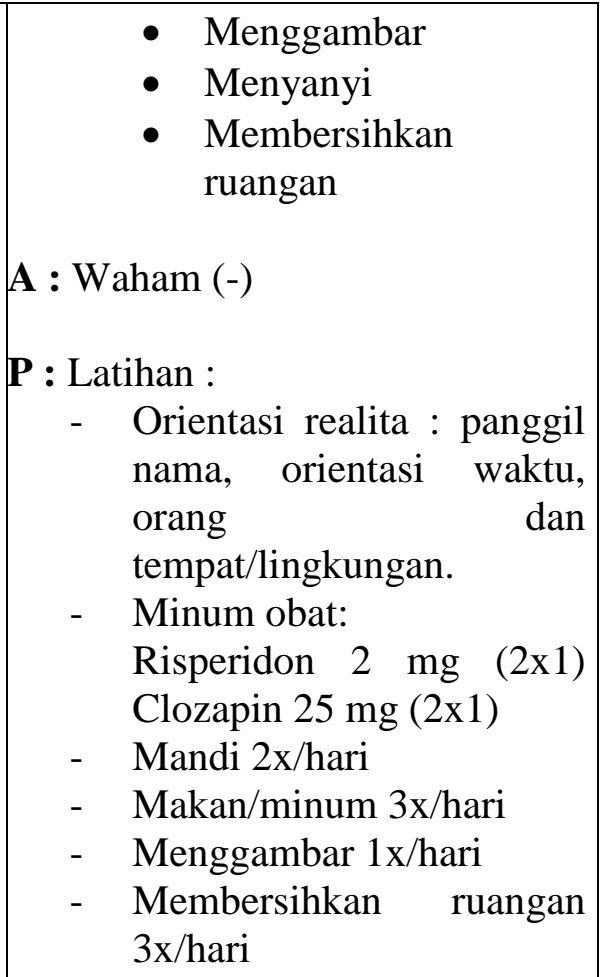 \\
\hline
\end{tabular}




\section{BAB 4 \\ PEMBAHASAN}

Setelah penulis melaksanakan asuhan keperawatan kepada Tn.M dengan waham di RSJ Prof. Dr. M. Ildrem Medan Sumatera, maka penulis pada BAB ini akan membahas kesenjangan antara teoritis dengan tinjauan kasus. Pembahasan dimulai melalui tahapan proses keperawatan yaitu pengkajian, diagnosa keperawatan, perencanaan, pelaksanaan dan evaluasi.

\subsection{Tahap Pengkajian}

Selama pengkajian dilakukan pengumpulan data dari beberapa sumber, yaitu dari pasien dan tenaga kesehatan di ruangan. Penulis mendapat sedikit kesulitan dalam menyimpulkan data karena keluarga pasien jarang mengunjungi pasien dikarenakan COVID-19 sehingga dibatasi pengunjung di RSJ. Maka penulis melakukan pendekatan kepada pasien melalui komunikasi teraupetik yang lebih terbuka membantu klien untuk memecahkan perasaannya dan juga melakukan observasi kepada pasien. Adapun upaya tersebut yaitu:

1. Melakukan pendekatan dan membina hubungan saling percaya diri pada klien agar klien lebih terbuka dan lebih percaya dengan menggunakan perasaan.

2. Mengadakan pengkajian klien dengan wawancara

3. Mengadakan pengkajian dengan cara membaca status, melihat buku rawatan dan bertanya kepada pegawai RSJ Prof. Dr. M. Ildrem Medan Sumatera

Dalam pengkajian ini, penulis tidak menemukan kesenjangan karena ditemukan hal sama seperti diteori: Menurut Herman (2020) tanda dan gejala waham seperti menolak makan, tidak peduli terhadap perawatan diri, ekspresi wajah yang sedih/gembira/ketakutan, gerakan yang tidak terkontrol, mudah tersinggung, pembicaraan yang tidak sesuai dengan kenyataan dan juga bukan kenyataan, menghindar dari orang lain, mendominasi pembicaraan, dan berbicara kasar. 
Tindakan keperawatan terapi generalis yang dilakukan padaa Tn.M adalah strategi pelaksanaan pertama hingga strategi pelaksanaan keempat pada gangguan proses pikir: waham. Strategi pelaksanaan I yaitu Pada Harga diri rendah dengan mengidentifikasi kemampuan dan aspek positif yang dimiliki klien. Strategi pelaksanaan kedua yaitu menilai kemampuan yang dapat digunakan, memilih/menetapkan kegiatan sesuai dengan kemampuan, melatih kegiatan sesuai dengan kemampuan yang dipilih 1 . Strategi pelaksanaan ketiga yaitu melatih kegiatan sesuai dengan kemampuan yang dipilih 2. Kemudian strategi pelaksanaan keempat yaitu melatih kegiatan sesuai dengan kemampuan yang dipilih 3.

Setelah diterapkan keempat strategi pelaksanaan pada harga diri rendah, kemudian dilanjutkan dengan strategi pelaksanaan pada gangguan proses pikir: waham. Strategi pertama meliputi latihan orientasi realita: orientasi orang, tempat, waktu, serta lingkungan sekitar. Strategi pelaksanaan kedua adalah minum obat secara teratur. Strategi pelaksanaan ketiga adalah melatih pemenuhan kebutuhan dasar. Strategi pelaksanaan keempat adalah melatih kemampuan positif yang dimiliki.

Kemudian dilanjutkan dengan strategi pelaksanaan pada Risiko Perilaku kekerasan. Strategi pertama meliputi latihan mengontrol perilaku kekerasan dengan cara: Latihan fisik 1: tarik nafas dalam, latihan fisik 2: pukul kasur bantal. Strategi pelaksanaan kedua yaitu minum obat secara teratur. strategi pelaksanaan ketiga adalah komunikasi secara verbal: asertif/bicara baik-baik. Strategi pelaksaan keempat yaitu spiritual.

\subsection{Diagnosa Keperawatan}

Menurut Nanda-I (2018) Diagnosa keperawatan yang yang menjadi penyebab Waham yaitu :

1. Koping individu tidak efektif

2. Isolasi sosial

3. Waham

4. Harga diri rendah 
5. Risiko perilaku kekerasan (Noveldy, 2019)

Pada Tn.M ditemukan 4 diagnosa keperawatan yang muncul yaitu Harga Diri Rendah, Gangguan Proses Pikir: Waham dan Risiko Perilaku Kekerasan dan koping individu tidak efektif. Dari hal tersebut dapat dilihat ada perbedaan antara teori dengan kasus, yaitu tidak semua diagnosa pada teori dialami oleh Tn.M, yaitu Tn. M tidak mengalami isolasi sosial. Sedangkan menurut stuart dan sundeen dalam Noveldy (2019) ia mengatakan bahwa ada 5 masalah yang muncul pada orang dengan masalah gangguan proses pikir: waham diantaranya adalah: koping individu tidak efektif, harga diri rendah, isolasi sosial, waham, dan risiko perilaku kekerasan.

\subsection{Tahap perencanaan}

Rencana tindakan keperawatan untuk klien dengan perubahan proses pikir: waham juga dapat dibuat dalam bentuk Strategi Pelaksanaan (SP) (Damaiyanti dan Iskandar, 2017). Perencanaan dalam proses keperawatan lebih dikenal dengan rencana asuhan keperawatan yang merupakan tahap selanjutnya setelah pangkajian dan penentuan diagnosa keperawatan. Pada tahap perencanaan penulis hanya menyusun rencana tindakan keperawatan sesuai dengan pohon masalah keperawatan yaitu : Gangguan proses pikir: Waham (Waham Kebesaran). Pada tahap ini antara tinjauan teoritis dan tinjaun kasus tidak ada kesenjangan sehingga penulis dapat melaksanakan tindakan seoptimal mungkin dan didukung dengan tersedianya sarana ruangan perawat yang baik dan adanya bimbingan dan petunjuk dari petugas kesehatan dari RSJ Prof. Dr. M. Ildrem Medan yang diberikan kepada penulis. Secara teoritis digunakan cara strategi pertemuan sesuai dengan diagnosa keperawatan yang muncul saat pengkajian. Adapun upaya yang dilakukan penulis yaitu :

1. Strategi Pelaksaan Pada Waham

a. Melatihan orientasi realita: panggil nama, orientasi waktu, orang dan tempat/lingkungan.

b. Menjelaskan cara minum obat secara teratur

c. Melatih cara memenuhi kebutuhan dasar klien 
d. Melatih kemampuan positif yang dipilih klien

2. Strategi Pelaksaan Pada Harga diri Rendah

a. Mengidentifikasi kekmampuan dan aspek positif yang dimiliki klien

b. Membantu klien menilai kegiatan sesuai kemampuan

c. Membantu klien menetapkan kegiatan sesuai kemampuan

d. Membantu klien melatih kegiatan sesuai kemampuan yang di pilih 1

e. Membantu klien melatih kegiatan sesuai kemampuan yang di pilih 2

f. Membantu klien melatih kegiatan sesuai kemampuan yang di pilih 3

5. Strategi Pelaksaan Pada Risiki Perilaku Kekerasan:

a. Melatih pasien mengontrol perilaku kekerasan dengan latihan fisik 1 : Tarik napas dalam

b. Melatih klien mengontrol perilaku kekerasan dengan latihan fisik 2 : Pukul Kasur bantal

c. Menjelaskan cara mengontrol perilaku kekerasan dengan minum obat

d. Melatih klien mengontrol Risiko Perilaku Kekerasan dengan berbicara baik-baik dengan orang lain

e. Mengevaluasi spritual klien

\subsection{Tahap Implementasi}

Pelaksanaan tindakan keperawatan disesuaikan dengan rencana tindakan keperawatan. Sebelum melaksanakan tindakan keperawatan yang telah direncanakan, perawat perlu memvalidasi apakah rencana tindakan keperawatan masih dibutuhkan dan sesuai dengan kondisi klien saat ini (Hartono, 2021).

Pada tahap implementasi, penulis mengatasi 3 masalah keperawatan yakni: diagnosa keperawatan Harga Diri Rendah, Gangguan Proses Pikir: Waham, Risiko Perilaku Kekerasan. Pada diagnosa keperawatan harga diri rendah strategi pelaksanaan pertama, mengidentifikasi kemampuan dan aspek positif yang dimiliki klien. Strategi pelaksanaan kedua yaitu menilai kemampuan 
yang dapat digunakan, memilih/menetapkan kegiatan sesuai dengan kemampuan, melatih kegiatan sesuai dengan kemampuan yang dipilih 1 . Strategi pelaksanaan ketiga yaitu melatih kegiatan sesuai dengan kemampuan yang dipilih 2. Kemudian strategi pelaksanaan keempat yaitu melatih kegiatan sesuai dengan kemampuan yang dipilih 3.

Kemudian Pada diagnosa keperawatan Gangguan Proses Pikir: Waham dilakukan strategi pelaksanaan yaitu latihan orientasi realita: orientasi orang, tempat, serta lingkungan sekitar. Strategi pelaksaan kedua yaitu minum obat secara teratur, strategi pelaksaan ketiga melatih pemenuhan dasar klien, strategi pelaksaan keempat yaitu melatih kemampuan positif yang dimiliki.

Setelah diterapkan keempat strategi pelaksaan pada gangguan proses pikir: waham, kemudian dilanjutkan dengan strategi pelaksanaan pada Risiko Perilaku Kekerasan dilakukan strategi pertemuan yaitu mengidentifikasi Perilaku Kekerasan, mengontrol perilaku kekerasan dengan cara tarik napas dan pukul kasur bantal. Strategi pelaksanaan yang kedua yaitu anjurkan minum obar secara teratur, strategi pelaksanaan ketiga yaitu latihan dengan cara komunikasi secara verbal atau bicara baik-baik strategi pelaksanaan ke empat yaitu Spritual.

\subsection{Tahap Evaluasi}

Menurut Damayanti (2017) pada tinjauan teoritis evaluasi yang diharapkan adalah :

1. Pada Gangguan Proses Pikir: Waham

- Pasien mempercayai perawat sebagai terapis

- Dapat mengendalikan Waham dengan melatih orientasi realita : orientasi orang, tempat, dan waktu serta lingkungan sekitar.

- Dapat mengendalikan Waham dengan cara minum obat secara teratur

- Dapat mengendalikan Waham dengan melatih cara pemenuhan kebutuhan dasar

- Dapat mengendalikan Waham dengan melatih kemampuan positif yang dimiliki 


\section{Pada Harga Diri Rendah}

- Mengetahui kemampuan dan aspek positif yang dimiliki.

- Mampu menilai kemampuan yang dapat digunakan,

- Mampu memilih/menetapkan kegiatan sesuai dengan kemampuan,

- Mampu melatih kegiatan sesuai dengan kemampuan yang dipilih 1.

- Mampu melatih kegiatan sesuai dengan kemampuan yang dipilih 2.

- Mampu melatih kegiatan sesuai dengan kemampuan yang dipilih 3.

3. Pada Risiko Perilaku Kekerasan

- Klien mempercayai perawat sebagai terapis

- Dapat mengidentifikasi dan mengontrol Risiko Perilaku Kekerasan

- Mampu mengendalikan Risiko Perilaku Kekerasan melalui latihan fisik,

- Mampu mengendalikan Risiko Perilaku Kekerasan dengan cara minumobat secara teratur

- Mampu mengendalikan Risiko Perilaku Kekerasan dengan berbicara baik-baik

- Mampu mengendalikan Risiko Perilaku Kekerasan dengan spritual yang terjadwal.

Pada tinjauan kasus evaluasi yang dihasilkan adalah :

1. Pada Waham

- Klien sudah dapat mengendalikan Waham dengan melatih orientasi realita : orientasi orang, tempat, dan waktu serta lingkungan sekitar.

- Klien dapat mengendalikan Waham dengan cara minum obat secara teratur

- Klien dapat mengendalikan Waham dengan melatih cara pemenuhan kebutuhan dasar

- Klien dapat mengendalikan Waham dengan melatih kemampuan positif yang dimiliki (menggambar) 


\section{Pada Harga Diri Rendah}

- Mengetahui kemampuan dan aspek positif yang dimiliki.

- Mampu menilai kemampuan yang dapat digunakan,

- Mampu memilih/menetapkan kegiatan sesuai dengan kemampuan,

- Mampu melatih kegiatan sesuai dengan kemampuan yang dipilih 1

- Mampu melatih kegiatan sesuai dengan kemampuan yang dipilih 2

- Mampu melatih kegiatan sesuai dengan kemampuan yang dipilih 3

3. Pada Risiko Perilaku Kekerasan

- Klien mempercayai perawat sebagai terapis

- Dapat mengidentifikasi dan mengontrol Risiko Perilaku Kekerasan

- Mampu mengendalikan Risiko Perilaku Kekerasan melalui latihan fisik,

- Mampu mengendalikan Risiko Perilaku Kekerasan dengan cara minumobat secara teratur

- Mampu mengendalikan Risiko Perilaku Kekerasan dengan berbicara baik-baik

- Mampu mengendalikan Risiko Perilaku Kekerasan dengan spritual yang terjadwal. 


\section{BAB 5 \\ KESIMPULAN DAN SARAN}

\subsection{Kesimpulan}

Setelah menguraikan tentang proses keperawatan pada Tn.M dan disimpulkan bahwa klien dapat beroirentasi secara realita, mengontrol risiko perilaku kekerasan dan mengatasi harga diri rendah dengan terapi yang di ajarkan oleh mahasiwa. Dimana klien dapat melakukan terapi generalis yang telah diajarkan oleh mahasiswa. Maka dapat diambil keputusan sebagai berikut Pengkajian yang dilaksanakan tidak banyak berbeda dengan pengkajian teoritis maupun penulis tidak mendapat kesulitan dalam pengkajian klien.

1. Pengkajian yang dilakukan tidak banyak berbeda dengan pengkajian teoritis dan penulis tidak mendapat kesulitan dalam pengkajian yang dilakukan

2. Dalam mengatasi masalah yang dihadapi klien, mahasiswa mapu Menyusun tindakan keperawatan sesuai dengan teoritis yang ada.

3. Dalam pelaksanaan tindakan keperawatan disesuaikan dengan perencanaan dan dapat dilaksanakan walaupun belum sepenuhnya dapat terlaksana.

4. Pada tahap evaluasi masalah yang dihadapi klien tidak teratasi semua sesuai dengan masalah klien.

\subsection{Saran}

1. Bagi Mahasiswa

Hendaknya mahasiswa/i dapat melakukan askep sesuai dengan tahapantahapan dari Standar Operasional Prosedur (SOP) dengan baik dan benar yang diperoleh selama masa pendidikan baik di akademik maupun dilapangan praktek.

2. Bagi Pasien

Diharapkan pasien dapat menerapkan terapi yang telah diberikan baik secara medik maupun terapi keperawatan yang telah diajarkan demi percepatan penyembuhan penyakit dengan masalah gangguan jiwa. 


\section{Bagi Perawat}

Diharapkan dapat menerapkan komunikasi terapeutik dalam pelaksanaan strategi pertemuan 1-4 pada klien dengan waham sehingga dapat mempercepat proses pemulihan klien.

4. Bagi Keluarga

Agar keluarga selalu memberikan motivasi kepada klien dan juga perawatan gangguan proses pikir: waham kebesaran dirumah.

5. Bagi Institusi Pendidikan

Dapat meningkatkan bimbingan klinik kepada mahasiswa profesi ners sehingga mahasiswa semakin mampu dalam melakukan asuhan keperawatan pada pasien-pasien yang mengalami waham kebesaran

6. Bagi Rumah Sakit

Laporan ini diharapkan dapat menjadi acuan dan referensi dalam memberikan asuhan keperawatan pada klien dengan waham kebesaran. 


\section{DAFTAR PUSTAKA}

1. Asis, S. J. De. (2018). Psychiatric Disorders Late in Life. Psychiatric Disorders Late in Life, 11-20. https://doi.org/10.1007/978-3-319-73078-3

2. Alif, A. S. (2017). Asuhan Keperawatan Jiwa Pada Pasien Waham Dengan Diagnosa Medis Skizofrenia Di Ruang Kenari Rumah Sakit Jiwa Menur Surabaya.

3. Arifianti, N. P. R. C. (2021). Gambaran Isi Waham Pada Pasien Gangguan Jiwa Di Uptd Puskesmas Abiansemal 1 Tahun 2021 (Doctoral dissertation, Perpustakaan Poltekkes Kemenkes Denpasar Jurusan Keperawatan 2021).

4. Amastuti, M. (2019). Asuhan Keperawatan Jiwa Pada Klien Dengan Perubahan Proses Pikir: Waham Nihilistik Di Desa Joton Kecamatan Jogonalan Kabupaten Klaten (Doctoral Dissertation, Stikes Muhammadiyah Klaten).

5. Azhimatu, R. (2017). Potensi Interaksi Obat Antipsikotik Pada Pasien Skizofrenia Paranoid Rawat Jalan Di Rsj Prof. Dr. Hb Saanin Padang Tahun 2015 (Doctoral Dissertation, Universitas Andalas).

6. Bell, V., Raihani, N., \& Wilkinson, S. (2019). De-Rationalising Delusions. 134. https://doi.org/10.1177/2167702620951553

7. Bintang, N. L. N. P. A. (2021). Gambaran Proses Berpikir Pada Pasien Skizofrenia Paranoid Di Uptd Puskesmas Gianyar Ii Tahun 2021 (Doctoral dissertation, Perpustakaan Poltekkes Kemenkes Denpasar Jurusan Keperawatan 2021).

8. Dwi Prastya, F., \& Arum Pratiwi, S. K. (2017). Mekanisme Koping Pada Pasien Perilaku Kekerasan Dengan Risiko Menciderai Orang Lain Dan Lingkungan (Doctoral dissertation, Universitas Muhammadiyah Surakarta). http://eprints.ums.ac.id/id/eprint/52420

9. Hastuti, R. Y., \& Setianingsih, S. (2016). Pengaruh Cognitive Behaviour Therapy Pada Klien Dengan Masalah Keperawatan Perilaku Kekerasan Dan Halusinasi Di Rsjd.

10. Dalami, E., Rochimah, N., Suryati, K. R., \& Lestari, W. (2009). Asuhan Keperawatan klien dengan gangguan jiwa.

11. Direja, A. H. (2011). Buku ajar asuhan keperawatan jiwa

12. ECA(2021)https://www.cdc.gov/eis/field-epi-manual/chapters/DescribingEpi-Data.html Diunduh 27 Febuari 2022

13. Eriawan, A. (2019). Asuhan Keperawatan Pada Klien Tn “O” Yang Mengalami 
Bipolar Dengan Masalah Keperawatan Waham Paranoid Di Ruangan Palm Rumah Sakit Khusus Daerah Dadi Provinsi Sulawesi Selatan Tahun 2019. https://lib.akpermpd.ac.id/index.php?p=show_detail\&id=1451

14. Fajariyah, E. Y. (2017). Penerapan Jadwal Kegiatan Activity Daily Living (Adl) Pada Pasien Skizofrenia Dengan Masalah Keperawatan Gangguan Proses Pikir: Waham Curiga Di Ruang Flamboyan Rs Jiwa Menur Surabaya.

15. Gelder M. Gath D. Mayou R. Et al. Oxfoidr Textbook of Psychiatri. 3th Edition. New York. Oxford University Press. Inc. 1996 : 9 - 15.

16. Hendarsyah, F. (2016). Diagnosis dan tatalaksana skizofrenia paranoid dengan gejala-gejala positif dan negatif. Jurnal Medula, 4(3), 57-62.

17. Husna, H. (2021). Studi Kasus: Asuhan Keperwatan Jiwa Pada Tn. B Dengan Risiko Perilaku Kekerasan.

18. Keliat, B. A., dkk. (2019). Asuhan Keperawatan Jiwa. Jakarta: Penerbit Buku Kedokteran EGC.

19. Keliat, B. A. (2009). Model praktik keperawatan profesional jiwa. Jakarta: EGC.

20. Keliat B, dkk. (2014). Proses Keperawatan Jiwa Edisi II. Jakarta: EGC

21. Keliat, B.A., \& Pawirowiyono, A. (2015). Keperawatan Jiwa Terapi Aktivitas Kelompok Edisi 2. Jakarta: EGC.

22. Laily, N. (2016). Penerapan Terapi Orientasi Realita (Tor) Pada Pasien Skizofrenia Dengan Masalah Keperawatanwaham Agama Di Ruang Flamboyan Rsj Menur Surabaya.

23. Kemenkes RI. (2018). Laporan Nasional Rist Kesehatan Dasar (riskesdas). Jakarta : Badan Penelitian dan Pengembangan Kesehatan.

24. Manao, B. M., \& Pardede, J. A. (2019). Correlation of Family Burden of The Prevention of Recurrence of Schizophrenia Patients. Mental Health, 4(1), 3142.

25. Muhith, Abdul. (2015). Pendidikan Keperawatan Jiwa. Jakarta: Penerbit ANDI.

26. Nailah Al-Firdausi, F., \& Reliani, S. K. (2015). Asuhan Keperawatan Jiwa Pada Tn. N Dengan Waham Kebesaran Dengan Diagnosa Medis Skizofrenia Paranoid Di Ruang Anggrek Rumah Sakit Jiwa Menur (Doctoral dissertation, Universitas Muhammadiyah Surabaya).

27. Nikmah, R. (2019). Penerapan Client Centered Care In Recovery Pada Pasien Skizofrenia Dengan Masalah Keperawatan Gangguan Proses Pikir: Waham Di 
Ruang Flamboyan Rumah Sakit Jiwa Menur Surabaya.

28. Nurjannah, I., Pamungkas, D. R., \& Warsini, S. (2017). Perbandingan Antara Diagnosis Yang Sering Ditegakkan Dan Possible Diagnosis Yang Diprediksikan Oleh Perawat Pada Klien Dengan Gangguan Jiwa. Jurnal Keperawatan Klinis dan Komunitas, 1(1).

29. Pardede, J. A., \& Siregar, R. A. (2016). Pendidikan Kesehatan Kepatuhan Minum Obat Terhadap Perubahan Gejala Halusinasi Pada Klienskizofrenia. Mental Health, 3(1).

30. Pardede, J. A., Keliat, B. A., \& Yulia, I. (2015). Kepatuhan dan Komitmen Klien Skizofrenia Meningkat Setelah Diberikan Acceptance And Commitment Therapy dan Pendidikan Kesehatan Kepatuhan Minum Obat. Jurnal Keperawatan Indonesia, 18(3), 157-166. https://doi.org/10.7454/jki.v18i3.419

31. Pardede, J. A., \& Purba, J. M. (2020). Family Support Related to Quality of Life on Schizophrenia Patients. Jurnal Ilmiah Permas: Jurnal Ilmiah STIKES Kendal, 10(4), 645-654.

32. Pardede, J. A. (2020). Terapi Keluarga. Jurnal Ilmiah Kesehatan

33. Pardede, J. A. (2022). Koping Keluarga Tidak Efektif Dengan Pendekatan Terapi Spesialis Keperawatan Jiwa.

34. Pardede, J. A., Siringo-ringo, L. M., Hulu, T. J., \& Miranda, A. (2021). Edukasi Kepatuhan Minum Obat Untuk Mencegah Kekambuhan Orang Dengan Skizofrenia. Jurnal Abdimas Mutiara, 2(2), 1-5.

35. Prakasa, A., \& Milkhatun, M. (2020). Analisis Rekam Medis Pasien Gangguan Proses Pikir Waham dengan Menggunakan Algoritma C4. 5 di Rumah Sakit Atma Husada Mahakam Samarinda. Borneo Student Research (BSR), 2(1), 815.

36. Pitayanti, A., \& Hartono, A. (2020). Sosialisasi Penyakit Skizofrenia Dalam Rangka Mengurangi Stigma Negatif Warga di Desa Tambakmas KebonsariMadiun. Journal of Community Engagement in Health, 3(2),300-303.

37. Prastika, Y., Mundakir, S. K., \& Reliani, S. K. (2014). Asuhan Keperawatan Jiwa Pada Pasien Waham Kebesaran Dengan Diagnosa Medis Skizofrenia Hebefrenik Di Ruang Flamboyan Rs Jiwa Menur Surabaya (Doctoral dissertation, Universitas Muhammadiyah Surabaya).

38. Rowland, dkk. (2019). Short-term outcome of first episode delusional disorder in an early intervention population. Schizophrenia Research, 204(xxxx), 7279. https://doi.org/10.1016/j.schres.2018.08.036 
39. Skelton, M., Khokhar, W. A., \& Thacker, S. P. (2015). Treatments for delusional disorder. Schizophrenia Bulletin. https://doi.org/10.1093/schbul/sbv080

40. Sulistiowati, N. M. D., Keliat, B. A., \& Wardani, I. Y. (2014). Pengaruh acceptance and commitment therapy terhadap gejala dan kemampuan klien dengan resiko perilaku kekerasan. Jurnal Keperawatan Jiwa, 2(1), 51-57. https://doi.org/10.26714/jkj.2.1.2014.51-57

41. Suripta, I. W. (2021). Asuhan Keperawatan Harga Diri Rendah Pada Tn Nb Yang Mengalami Skizofrenia Hebefrenik Di Ruang Nakula Rumah Sakit Jiwa Provinsi Bali (Doctoral dissertation, Poltekkes Kemenkes Denpasar).

42. Suryenti, V. (2017). Dukungan Dan Beban Keluarga Dengan Kemampuan Keluarga Merawat Pasien Resiko Perilaku Kekerasan Di Klinik Jiwa Rumah Sakit Jiwa Provinsi Jambi Tahun 2017. Jurnal Psikologi Jambi, 2(2), 39-46.

43. Sumbarta, M. I. (2017). Penerapan Cognitive Behavior Therapy (Cbt) Pada Klien Skizofrenia Dengan Masalah Keperawatan Gangguan Proses Pikir: Waham Agama Di Ruang Flamboyan Rumah Sakit Jiwa Menur Surabaya.

44. Sofian, R. (2017). Asuhan Keperawatan jiwa dengan kasus waham kebesaran pada Tn. K di RSJ Radjiman Wediodiningrat Lawang (Doctoral dissertation, STIKes Maharani Malang).

45. Stuart \& Laraia. (2005). Principles dan Pratice of Psychiatric Nursing. 8th Edition.St.Louis:Mosby.

46. Townsend, M. C., \& Morgan, K. I. (2017). Psychiatric mental health nursing: Concepts of care in evidence-based practice. FA Davis.

47. Victoryna, F., Wardani, I. Y., \& Fauziah, F. (2020). Penerapan Standar Asuhan Keperawatan Jiwa Ners untuk Menurunkan Intensitas Waham Pasien Skizofrenia. Jurnal Keperawatan Jiwa (JKJ): Persatuan Perawat Nasional Indonesia, 8(1), 45-52. https://doi.org/10.26714/jkj.8.1.2020.45-52

48. World Health Organization. (2016). Scizofrenia. https://www.who.int/newsroom/fact-sheets/detail/schizophrenia

49. Yusuf, A., PK, R. F., \& Nihayati, H. E (2015). Buku ajar keperawatan kesehatan jiwa. Jakarta : Salemba.

50. Zukna, N. A. M., \& Lisiswanti, R. (2017). Pasien dengan Halusinasi dan Waham Bizarre. Jurnal Medula, 7(1), 38-42. 